\title{
ETHNOGRAFISCHE MEDEDEELINGEN OVER DE DAJAKS IN DE AFDEELING KOEALAKAPOEAS.
}

(RES. ZUIDER- EN OOSTERAFD. VAN BORNEO).

DOOR

J. MALLINCKRODT. CONTROLEUR B.B.

\section{HOOFDSTUK II. ${ }^{1}$ )}

\section{De Godsdienst.}

$\$ 26$. Het an imisme.

De Dajaks zijn - eenige honderden Christenen daar gelaten -

allen animisten. Zooals we in $\$ 1$ zagen worden de geislamiseerde Dajaks gerekend onder de Maleiers. In zijn animistische geloofsovertuiging ziet de Dajak alle levende en levenlooze zaken als bezield, en gelooft hij dat bij tijd en wijle de zielen dezer voorwerpen hun omhulsel kunnen verlaten, en vrijelijk rondzwerven. In dien toestand kunnen zij zoowel een invloed ten goede, als ten kwade op hem hebben. Speciaal ten aanzien van dingen waarvan hij in hooge mate afhankelijk is, of die door verschillende omstandigheden indruk op hem maken, acht hij zich tot voorzichtigheid gedwongen, en zal hij trachten zich de goede gezindheid dier zielen te verzekeren, hij zal althans beproeven ontstemming te zijnen opzichte te voorkomen. Als goed bekend staande zielen zullen zich dan ook minder in zijn belangstelling verheugen dan die, welke moeilijk zijn in den omgang. Tot de eersten zal hij zich slechts wenden wanneer hij speciale wenschen heeft waarvan hem de bereiking - zonder deze hoogere tusschenkomst - niet gemakkelijk voorkomt.

1) Bij de in dit hoofdstuk voorkomende eigennamen is, hoewel meermalen twijfel rees aan de consequente doorvoering van de schrijfwijze, het Ms. letterlijk gevolgd.

(RED.). 
Voor zich zelven neemt hij natuurlijk evenzeer aan, dat er een ziel in zijn lichaam huist. De verandering, die plaats heeft bij zijn overlijden acht hij ontstaan doordien zijn ziel het lichaam heeft verlaten. Met deze enkele ziel kwam hij echter niet toe, er waren toestanden en voorvallen in zijn leven, die hij niet anders kon verklaren, dan door aan te nemen, dat hij nog een tweede ziel had. Deze tweede nu, door Dr. A. C. Kruyt *zielestof genoemd, was vrij in haar bewegen, en verliet b.v. in toestanden van bewusteloosheid het lichaam; ook bij droomen was deze het, die de gedroomde wederwaardigheden beleefde, op haar omzwervingen op de aarde.

Deze laatste nu kan oorzaak zijn van het verdwijnen der eigenlijke ziel. Verlaat toch de zielestof het lichaam op een daartoe niet geschikten tijd, dan wel wordt zij door een boos wezen ontvreemd, dan ontstaat ziekte van ernstigen aard, maar ook kan een of ander hooger wezen en ook een mensch de ziel ziek maken, in welk geval ook het lichaam ziek wordt. Indien een ander wereldburger bezweringen houdt, of handelingen onderneemt met voorwerpen een ander toebehoorend - we zullen daarvan hieronder nader spreken - dan kan hij het daartoe leiden, dat de ziel ziek wordt, dan wel in conflict komt met de ziel van het voorwerp, dat bij de handeling gebruikt is. Nagenoeg bij elke overtreding tegen de heerschende gebruiken zullen we dan ook strafbepalingen - om zoo te zeggen bijkomende straffen - zien opgenomen, die de bedreigde ziel moeten versterken. Straffen die veelal bestaan uit een kleine ceremonie, waarbij de bedreigde met bloed bestreken wordt (manjaki Ngad.) (basangkolan (K.W.).'

De zielestof huisvest, om het zoo uit te drukken, in de ziel. Is nu de eerste langen tijd afwezig, dan zal ten slotte de ziel zich verwijderen en dit heeft den dood ten gevolge; het is dus zaak die zielestof ten spoedigste terug te bekomen, waarvoor dan ook bezweringen in zwang zijn, die beneden behandeld zullen worden. Ook bij ziekte der zielestof zal ten slotte de ziel verdwijnen. Men moet dus alweer trachten de oorzaak der ziekte op te sporen. Verdwijnt de zielestof voor goed, dan ontwijkt op hetzelfde oogenblik ook de ziel.

Komt een mensch op bepaalde wijze, bv. in zijn droomen in aanraking met boomen, steenen, menschen enz., dan zijn dit ontmoetingen der zielen dezer voorwerpen met de zijne. Op die 
wijze kan hij ook waardevolle gegevens verkrijgen, die hem van nut kunnen zijn in zijn primitief bestaan. Op die wijze worden hem bv. stukjes hout aangewezen, die hem zullen kunnen beschermen tegen ongelukken op dit ondermaansche; zoo worden de pahewan (woonplaatsen van geesten) hem kenbaar gemaakt, enz.

\section{\$ 27 De zielen der menschen.}

De beide bovenbedoelde zielen dragen verschillende namen, die ook plaatselijk verschillen. De zielestof wordt genoemd: penjaloempoeh (Sar. Sah.), saloeka (Ott D.), de ziel: hambaruan (Ngad.), semengat (Sah.) dahibaun (Sar.) maroewai (Ott D.). Verlaat de penjaloempoeh het lichaam dan zal ze de fontanel als weg daartoe kiezen. Soms ziet men zulks, bv. bij een slapende, die door een vriend(in) op ongedierte wordt nagekeken; het wil dan wel eens gebeuren, dat men een kleine duizendpoot zich haastig ziet verwijderen. Voor hem die dit ziet, is zulks een zeer gunstig voorteeken dat men bij de Katingan, katoeaan, bij de Sahiai toea bahambit noemt. Het is natuurlijk, dat de Dajak U talrijke verhalen van dien aard kan opdisschen om zijne beweringen te staven. Ter verduidelijking geef ik een der meest voorkomende: Een man lag te slapen, terwijl zijn vrouw hem vlooide; plotseling zag ze een kleine duizendpoot uit het haar kruipen. Ze liet het dier begaan, dat op den grond aangeland, over een klein stokje, dat over een plas lag, liep en na eenigen tijd weer terugkeerde naar zijn plaats van herkomst. De man ontwakende, deed zijn vrouw een verhaal, als had hij gedroomd over een lange brug te loopen, die over een uitgestrekt meer gebouwd was en hoe hij midden op de brug naar beneden ziende, daar een zeer ouden heiligen pot had gezien. De vrouw deelde natuurlijk haar man ook haar verhaal mee en samen togen ze aan het werk, om na korten tijd het kostbare vaatwerk aan den dag te brengen. $\mathrm{Na}$ dien tijd had men steeds geluk in al zijn handelingen.

Zoowel de Dajak als de Maleier zal dan ook nooit in zijn huis zoo'n kleine duizendpoot doodmaken als er iemand in het vertrek slapende is. Men moet dien persoon daartoe eerst wakker maken, het zou toch kunnen zijn, dat het rondscharrelende dier, de ziel der slapende is. Zoo kan ook plotseling iemand wakker maken gevaarlijk zijn, want hoewel de penjaloempoeh 
zich uiterst snel kan bewegen, kan hij toch te laat komen; in dat geval zou de slaper ziek worden.

Een andere mogelijkheid is, dat terwijl de penjaloempoeh wandelende is, hij door een ander persoon wordt weggevangen, het is hem dan - mits goed opgeborgen - onmogelijk terug te keeren. Men vertelt dat zulks wel gedaan wordt door vijanden, die allerhande bezweringen houden, hun door hooger machten geleerd. Men zal een feest moeten houden om deze bezweringen krachteloos te maken, of wel de vijand biedt aan - natuurlijk niet voor niets - de verloren geraakte kostbaarheid terug te bezorgen. Als iemand sukkelende is, meent men dat zijn penjaloempoeh zich heeft verwijderd, hij zal deze dan s'avonds terug roepen met een roep alsof hij kippen lokt. Terzelfder tijd zal hij een kommetje met olie klaar zetten; valt daar nu binnen afzienbaren tijd een diertje in, dan is dat een teeken dat de ziel is teruggekeerd, het diertje is niet meer dan het leege omhulsel van het levenselement. De persoon zal dan spoedig herstellen van zijn zwakheid.

Indien de mensch overlijdt, heeft men niets meer te maken met de penjaloempoeh; deze verdwijnt, of is dood. Anders staat het echter met de semanget of hambaroean; deze toch zal na den dood een nieuw bestaan voeren als rio (Sah., Ott D.), lian (Kat. Ngad.) of padara (K. W.). Het is hier echter nog niet de plaats over een en ander te handelen.

$\S 28$. De hoogere wezens.

Wij hebben dan gezien hoe elk voorwerp zijn ziel (ganagana) heeft ${ }^{1}$ ), doch daarmee hebben we nog slechts met een zeer klein deel der invloeden kennis gemaakt die op den Dajak werken.

Allereerst dan moet het hoogste wezen, de God der Dajaks worden genoemd. Zijn naam is Mahatara, of zooals in Kota Waringin Sangiang Dewata. Hij is weinig bekend, en verheugt zich ook niet zeer in de attentie der geloovigen. Men ziet hem nog slechts te voorschijn komen in de oude verhalen, slechts bij hooge uitzondering roept men hem aan. Hij is de schepper der wereld, waarbij hij echter door verschillende andere goden

1) De rijst alleen verheugt zich in een hambaroean. Deze echter is de ziel van de rijst in het algemeen, elke korrel afzonderlijk bezit een gana de zgn. ganan parei die bij bezweringen een belangrijk werk doet, zooals we zullen zien. Ook bij de heilige potten spreekt men slechts van gana (ganan blanga, gahalamang). 
is geholpen, in het bijzonder door zijn Sanger ${ }^{1}$ ) nl. Djata. Te dier tijde waren er reeds talrijke andere goden; we zullen ze leeren kennen, als de vorsten van geluk en voorspoed, ongeluk, goud enz. In welke verhouding ze tot den God stonden is niet met zekerheid te zeggen. Wellicht moet men ze slechts als zijn krachten beschouwen. Slechts eenige hunner (er zijn er veertien) worden aangeroepen.

Mahatara woont in den hoogsten hemel, waarvan er zeven zijn. Djata's rijk bestaat uit drie afdeelingen; de toegangen daartoe liggen in de diepe rivierbochten: labehoe (Ng.) to-oek (Sar.). Was er aanvankelijk slechts één Djata, ook hiervan zijn er thans ontelbare, elk een speciale labehoe als toegang tot zijn verblijf hebbende. Wij zullen later zien hoe men daar offers opstelt om hun hulp te verkrijgen.

Van verreweg het meeste belang echter zijn de Sangiang of luchtgeesten, die in het verblijf lewoen Sangiang wonen, zijnde dit een der oudste lagen van den hemel, een groot rivierland, waar elke Sangiang zijn stroomgebied heeft.

Ze zijn den mensch behulpzaam en worden veelvuldig aangeroepen. Aan de verschillende rivieren ziet men afwijkende hemelbeschrijvingen, en ook andere namen voor deze machten.

De oorsprong der Sangiang kan het best worden nagegaan aan de hand van de Ngadjoesche legende terzake, die ons tevens zal inlichten over het ontstaan van andere hoogere machten. Daarna zullen we zien hoe een en ander elders is.

\section{\$29. De oorsprong der Sangiang.}

Nadat Mahatara de aarde had geschapen, wenschte hij ze ook te doen bewonen. Hij makkte toen aan een tak van den Ganingboom, aan elk uiteinde, een menschenbeeld, aan den eenen kant een man, aan den anderen kant eene vrouw. Dezen stok wierp hij op aarde, het mannenbeeld kwam in het water te liggen, het vrouwenbeeld op het land. In het midden was de stok doorgebroken, en het mannenbeeld dreef weg. Nadat hij dicht bij de riviermonding was aangespoeld op een eilandje kwam hij tot leven. Zijn naam was: Toenggal Garing Djandja. hoenan Laoet. (De eenige Garing die uit de zee is verrezen). Inmiddels was ook het vrouwenbeeld tot leven gekomen; de

1) Sanger is de verhouding waarin twee mannen tot elkaar staan wier kinderen samen gehuwd zijn. 
vrouw droeg den naam: Poetri Boelau Djoelah Karangan. (De gouden prinses, die uitsteekt uit den oever). $\mathrm{Zij}$ nam een pinangscheede en roeide daarin stroomafwaarts; de man was inmiddels op een stuk hout naar boven geroeid.

De beiden leefden samen, eerst in de boot van de vrouw; na eenigen tijd echter begon ze te menstrueeren, hetgeen haar een ongeluksteeken voorkwam.

Het bloed wierp zij in het water en daaruit ontstonden alle booze watergeesten. Toen ging men op het land wonen met hetzelfde resultaat; het bloed viel op aarde en daaruit werden de booze aardgeesten. $\mathrm{Zij}$ bouwden zich nu een huis en gingen voort als voorheen, doch geen verandering was merkbaar. $\mathrm{Bij}$ deze derde gelegenheid werd het beeld, in een pinangblad gewikkeld, in een boom geworpen, en daaruit werden de boomduivels.

Thans echter kwam Mahatara, hij deelde den twee mede, dat zij verkeerd hadden gedaan, door zoo maar samen te leven, dit moest gebeuren op een wijze zooals hij dat thans mededeelde, men moest van dit voornemen kennis geven aan alle wezens en besmeerd worden met bloed (manjaki mamalas).

Zoo gaf dan Mahatara al die regels die nog thans gebruikt worden bij de huwelijksplechtigheid.

Nadat nu hieraan voldaan was zien we dat, toen Poetri Boelau's tijd daar was, zij drie zonen ter wereld bracht nl. Maharadja Sangiang, Marahadja Sangen en Maharadja Boenoe.

In die dagen was het nog een Paradijs op aarde, hemel en aarde waren toen één en de hemelstof diende den mensch tot voedsel.

Bij hun geboorte hadden alle drie kinderen een geschenk gekregen van God. Maharadja Sangen was in het genot gesteld van allerlei nuttige zaden, hij hield zich bezig met deze te planten, ten voordeele der menschheid die later zou ontstaan.

Maharadja Sangiang was met ijzer begiftigd, echter met een soort, dat den mensch wel tijdelijk buiten gevecht kon stellen, maar niet kon dooden; dit was het z.g.n. Sanaman lampang (drijvend ijzer). Maharadja Boenoe echter kreeg een uiterst gevaarlijk speeltuig n.l. een ijzer, dat wel dooden kon (Sanaman leteng). Waar deze broers voortdurend twisten, zien we Mahatara om zoo te zeggen elken dag met het danoem (leven verwekkend water) heen en weer gaan tusschen zijn woonplaats en die der aardbewoners om een getroffene tot het leven terug te brengen. 
Ten slotte verdroot hem en de ouders dit gekibbel, en zoo gebeurde het dat Hemel en Aarde van elkaar gescheiden werden en Maharadja Boenoe alleen achter bleef. Arm en verlaten dwaalde hij rond, overal zocht hij. Wel is waar stonden hem de door Sangen geplante vruchtboomen ten dienste, maar hij wenschte zich een vrouw. Toen hij nergens andere menschen aantrof besloot hij een pop van klei te maken.

Deze gereed zijnde verzocht hij Mahatara dit beeld levend te maken, hetgeen de God toezegde.

In den tijd echter dat hij wachtte, kwam een dier tot hem, n.l. een Angoi. Deze bespotte hem omdat hij om die pop levend te maken de hulp van Mahatara noodig had, en zei dat hij dat ook wel kon doen.

Maharadja Boenoe stemde er in toe, dat Angoi zijn kunsten vertoonde; de pop werd levend en kreeg den naam Hanteloe Petak. Juist op dat moment kwam Mahatara met zijn danoem Kahiringan, en was hoogelijk ontstemd over het gebeurde. Aangezien de pop door een sterfelijk wezen - de Angoi - tot leven was gebracht, zou ook eenmaal de vrouw moeten sterven, hetgeen na het gebruik van Danoem Kahiringan niet het geval zou zijn geweest. De menschen nu stammen van dit echtpaar af en zijn om die reden sterfelijk. Maharadja Sangiang en Maharadja Sangen waren inmiddels ook getrouwd met Poetri Kambang Amboen Hatantali en Poetri Kambamg Garing (Prinses Bloem van den ragfijnen nevel en Prinses Garing bloesem), en werden de stamouders der beide geslachten van luchtgeesten de Sangiang en de Sangen. Deze laatste spelen echter geen rol in het gewone leven. De stam der Sangiang is echter zeer belangrijk. Naar de Sangen noemt men ook de heldendichten die men 's avonds pleegt te zingen: Sangen.

We zien dan acht geslachten elkaar opvolgen welker namen wel bekend zijn, maar in dit verband zijn die van minder belang. De achtste echter zou de eigenlijke stamvader worden van de Goden, die den mensch hunne diensten presteeren. Dit was Tantolang Boelan (hij die gouden beenderen heeft). Deze bekwam twee kinderen nl. Radja Pampoelau Hawon en een dochter Kamilau Panjoelau Bintang, welke laatste in het huwelijk trad met haar neef Radja Pendjarawan Ketingan.

Beiden kregen nu veertien kinderen, zeven zonen en zeven dochters elk.

Dl. 80. 
De eerste kreeg: 1. Radja Dohong Boelau, 2. Pandjoendai Lanka Mamat Tempoeng Baroen, 3. Rahoen Tinggang Njampoelau Bahandang, 4. Talantang Sawang Boeang Tolang, 5. Boedjang Berendang dia baka impoen lawa, 6 Sahawang Boelau tempoen Berang penja, 7 Rawing Tempon Telon loemba baharoen boelau, als zonen en voorts zeven dochters n.l.:

1. Saring Boenga Mina djalembang tinggaring, 2. Oedjan Boelau kankalingan andau, 3. Pergantian Boelau, 4. Perahimoek Tatawa, 5. Riwoet Garantoeng manambeleng Sambang, 6. Bawi Toeroen boelau menjamben Njahau, 7. Tempon Hendau Boelau.

Het andere echtpaar verwekte zeven dochters n.l.:

1. Rampan Bawi hai mengawang Ngamboeloeng Loemba, 2. Baloen tamboek pandak indoe boelau kambahan, 3. Loeang Tandang Maheirai boenga, 4. Garing balemo sangkabilang Roentoen, 5. Bawi balang babilem mina asoek kasanparoeng, 6. Boenga Boelau Bawi Randan, 7 Kemaloeh Tempoen Tiawon.

Voorts zeven zonen : 1. Radja Ngambang Boelau, 2. Lalenda Lioe, 3. Marakahan Tingang, 4. Sari kambang Boenga, 5. Tanteloeh Tingang, 6. Tawon Baboekan Soeling Nangai Andang Ngababilai Langit, 7. Tempoen kenarian Sawang.

Van de verhalen, die aangaande deze goden in omloop zijn, zijn vooral die betreffende Tempon Telon geliefd. We zien hem aanvankelijk als een bloedklomp geboren worden, weggeworpen door zijn moeder de rivier afdrijven, waar eene andere Sangiangvrouw (Poeson Baloeso) hem bij Boekit Lengkong vindt, hem tot Sangiang maakt en hem den naam Kampang Boelau panaroesan langit (de gouden zwaardschede, die onder den hemel voortdreef) gaf. We hooren van menigen strijd door hem gestreden tegen kwade geesten, eindigende met overwinning op Manjamai, een gevreesd Sangiang, die het Tempoen Tiawan lastig maakte. Beide, Tempoen Tiawan en haar bevrijder keeren nu naar de woonplaats der vrouw terug en daar trouwen ze; te zelfder tijd trouwen ook de broeders en zusters. Zij vestigen zich dan, de mannen, in de gebieden hunner vrouwen, zooals de adat dat meebrengt, en de dochters van Papoelan Hawon aan de Batang Danam Djalajan, de anderen aan de Batang Danoem Barirai.

Het land der Sangiang n.l. is een groot rivierland, waar elke stam zijn eigen gebied bewoont. Teekeningen van deze streken zijn niet zeldzaam.

Al deze Sangiangs zijn echter niet even belangrijk; de voor- 
naamste is Tempon Telon, die zijn naam dankt aan zekeren Telon, die hem zijn onderwerping aanbood na de overwinning op Manjamai. (Telon is dan ook in de Sangiangtaal de naam voor slaaf).

Een andere Sangiang, die hem zijn diensten aanbood was Asai Menteng, de moedige. Als Tempon Telon zijn werk verricht - d.i. als hij de zielen der afgestorvenen in zijn ijzeren schip ‘Banama sanaman, naar 't zielenland (lewoen liau) brengt, fungeert Asai Menteng als djoeroe batoe. Zijn vreeselijk en angstwekkend uiterlijk heeft menige rotanvlechtster reeds geinspireerd bij het bewerken harer matten.

Men pleegt Tempon Telon veelvuldig aan te roepen evenals zijn oudsten broer en oudsten en jongsten zwager.

Zijn nu de Goden onder deze namen het eigendom der Ngadjoe's, er is één geslacht, dat in heel Zuid-Borneo wordt gekend en aangeroepen. Dat is Sangoemang met zijn helper Papaloi en de steeds door zijn schoonzoon, Sangoemang, bedrogen Maharadja Hadji. De verhalen aangaande dit driemanschap in omloop zijn meer van den vroolijken kant.

Als Sangoemang echter zijn aardigheden tijdelijk staakt, is hij een der meest geliefde - zoo niet de meest in aanzien staande Sangiang; hij wordt zeer veel ter hulp geroepen, aan hem doet men talrijke beloften, tallooze boschjes zijn aan hem gewijd. We zullen later zien hoe men kinderen aan hem opdraagt, opdat ze gezond zullen blijven.

Men neemt nu plaatselijk meestal een bepaalden Sangiang aan, die als schutspatroon der familie of van de vestiging geldt; naast de aardgeesten wordt bij voorkomende gelegenheden ook deze aangeroepen om zijn vereerders hulp te verleenen. Dit neemt natuurlijk niet weg, dat men ook anderen om hulp mag verzoeken; dit laatste heeft meestal plaats bij belangrijke aangelegenheden, dan wel ingeval de schutsheilige zijn plichten slecht vervult.

In het Kota Waringinsche noemt men al deze godheden met den verzamelnaam Sangiang Doewata, dezelfde naam dus die de schepper der wereld en stamvader der menschheid draagt. Ook daar hebben echter verschillende lamans en watassen hun eigen speciale Sangiang Doewata's; evenzeer heeft elke familie zijn schutsheilige van dien naam.

Ik vernam slechts van een dusdanig hooger wezen, dat een bepaalden naam draagt, dit was de beheerscher des hemels van 
Lamandau Dajaks (Boekit Sebajan), die Raden Sangen Loempoeng Pojang heet.

Het ontstaan der menschen wordt ons in Kota Waringin als volgt verteld. Nadat Sangiang Doewata de aarde geschapen had zond hij zijn zoon en dochter (Bagalah en Batara) naar de aarde om deze te bevolken. Batara daalde met haar slavin Baromas op den boom Kansoerai neer, terwijl Bagalah met zijn slaaf Soeri Boejang uit het water verrees. Zich aan den oever neerzettende, zag hij in het water het beeld van eene vrouw; hoe hij echter zocht, onder water vond hij haar niet. Mistroostig op den oever zittende hoorde hij een Maniboei in den boom geluid maken, en opziende ontwaarde hij de vrouwen.

Hij huwde met de vrouw; slaaf en slavin huwden ook. Zij werden de stamouders der orang soeka en der hoeloen. Van de meegebrachte vruchten plantten ze verscheidene soorten n.l. sawang, doerian, sangkawang, pinang en klapper. We zullen later zien, hoe al deze gewassen hun doel hebben bij de gebruiken, bij de Dajaks aldaar in zwang. Behalve die personen daalden nog andere goddelijke wezens neer. de z.g.n. Lamambang, die we evenzoo later nog zullen ontmoeten.

Aan de Saroejan, waar men de luchtgeesten dewa of ook wel, evenals de oerai, djaja noemt, wonen deze in dorpen aan een rivier.

We hebben daar, in het topje der godenverblijfplaats aanvangende, de navolgende Goden:

Roetjoeng baloen Djambang

Boedjang Karoetoh haboen Bangoe

Boedjang toekang Roedjoe Diang

wonende in Roboe ${ }^{1}$ ) Rottoh Haboen Bangoe.

Harendah Inai Kaneirai Roeroh $=$ die in Roboe Riang Toenggoep Langit woont.

Harendah Bioh Kangidai Baroe = die in Roboe Toembang Danoem Njampang huist.

Kamoeroeng botoh Kandang: in Najang Njaroeng Poerang.

Habendang Manjan: in Tapakang Rantau Hintan.

Rindai Pandan: in Papan Dara Boeran.

Habinang anak Sangoemang: in Habinoei Oett Rasan Kapoet.

Rantei dei Merai; in Toembang Samben Sabang.

Pandan Baroen : in Roboe Tangkoe loenoek Njanjan.

1) Roboe of Obboe beteekent aan de Saroejuh dorp dan wel land. 
Hebben we dus thans nagegaan welke luchtgeesten alzoo het leven der Dajaks beheerschen, daarbij mogen niet vergeten worden eenige zeer belangrijke, welke in de Ngadjoesche streken met Mahatara zelf op één lijn worden gesteld, en door de Kahajansche bevolking worden beschouwd als de broers van God.

1. Radja Toentoeng Matan Andau, 2. Radja Erang Mandan, 3. Radja Belarang Boelau, beter bekend onder den naam "Radjan Oentoeng», 4. Radjan pemisie Andan, 5. Radjan berkat, 6. Radjan Temanang, 7. Radjan sial, 8. Poetri Selang Temananag, 9. Poetri Belawang Boelan, 10. Poetri Belawang Roendjan, 11. Poetri Belawang Boelau, 12. Poetri Bakoewoe Hintan, 13. Poetri Soeloeh Loempoeng Matan Andan.

Ten slotte hebben we dan nog als van gelijken ouderdom als God Kadjangga Hatoeën Boelan, op zijn Hollandsch: het mannetje in de maan.

Hebben we nu gezien welke hoogere wezens boven ons vertoeven, thans moeten we nagaan welke geesten enz. ons op aarde kunnen lastig vallen, behalve degene, die we reeds vroeger behandelden.

\section{$\$ 29$. Geesten en spoken.}

De bovennatuurlijke krachten die op den mensch werken, kunnen zijn van menschelijken en van hoogeren oorsprong. Onder de laatsten hebben we te rekenen de boom-, aard- en watergeesten (niet gelijk te stellen met de oerai) die uit het menstruatie-bloed der eerste vrouw ontstonden. Het zijn allen kwade geesten of kwelgeesten, die niet deelen in de offers aan de oerai gebracht; wel offert men hun, zoodra men van hunne tegenwoordigheid kennis krijgt. Zoo heeft men onder anderen de roodharige kwelduivels, de Njaring, die de niboeng-boomen bewonen. Voorts wonen ze in Pahewan, waar men hun offers brengt, en somtijds beloften (hadjat) doet.

Een ander soort van kwelgeesten, die evenzoo in het bosch huizen zijn de Karaja's. Het zijn schepsels, die naar willekeur groot en klein kunnen worden, maar meestal zich vertoonen in den vorm van kleine kinderen, zonder kleeding. Ze dwalen door de bosschen en maken de boschproducten zoek, of ze sluipen in de pondok van den verzamelaar en eten zijn middag- 
maal op. Ook ontmoet men ze wel in de gedaante van een stuk wild; dit te vangen is niet doenlijk, men dwaalt in het vuur van de jacht af, en komt meestal niet voor den avond tot de ontdekking met een Karaja te doen te hebben gehad. Ook de Maleiers weten er staaltjes van te vertellen. Menigmaal toch zouden ze lieden in het bosch zijn tegengekomen, waarmee ze al pratend voort liepen, om als ze goed en wel verdwaald zijn door de kwelgeest verlaten te worden. Men noemt ze nok kariau's.

Zeer talrijk zijn zulke geesten, maar het komt niet noodzakelijk voor ze allen te behandelen. Doch eenigen ervan zijn der moeite waard; zij toch zijn van menschelijken oorsprong.

Allereerst dan de beruchte hantoe hoedjan panas (Mal.), mandar (Daj.). Er was in vroeger jaren een Dajak, wiens vrouw zwanger was en die een groote lust gevoelde in hertenvleesch. De man ging op haar verzoek op jacht, maar hoe hij ook zocht, hij vond niets. Daarbij was hij verdwaald en na weken loopen ten slotte tot spook geworden. De zoon die hem geboren werd, ging toen hij daartoe oud genoeg was, op zoek om zijn vader te vinden. Hij vond hem ook inderdaad, maar kon hem niet overhalen, naar huis terug te komen. Hij kreeg echter den wenk om als het regende en de zon scheen een levend boomtakje achter zijn oor te steken; dit zou het teeken zijn van zijne afstamming, en kon hem geen kwaad geschieden. Wie echter niet zoo beschermd is, dien zal hij treffen met zijn soempitan (blaasroer), en dit zal pijn in den rug en ten slotte den dood veroorzaken.

Men zal dan ook bij die gelegenheid de Maleiers, zoowel als de Dajaks, zich met zulk een takje zien sieren.

Een andere soort van spoken zijn die welke Maleiers en Dajaks dezer streken hantoeën plegen te noemen. Dit zijn wel de meest gevreesde wezens die men kent, en, indien er geen Gouvernement was, zou menigeen het lot treffen der Europeesche heks, hetgeen niet wegneemt dat nog tegenwoordig in de bovenlanden, vooral van Koeroen, menige moordzaak daarin haar oorzaak heeft.

Dit nu zijn erfelijk belasten, en wel met de zeer merkwaardige kwaal, dat ze bij nacht en ontij het hoofd van den romp trekken en met ingewanden en wat daarbij behoort de lucht in vliegen, zich middels hun ooren voortbewegende. De ingewanden stralen 
licht uit. Deze hantoeën, of aloean zouden naar het verhaal wil van de Kahajan afkomstig zijn. Toen ze zich daar een huis bouwden, vonden ze in een der gaten voor de huispalen een vette slang. Deze werd verorberd en 's avonds waren allen tot hantoeën geworden. Dit euvel nu is erfelijk en geen zich respecteerende familie zal iemand, die als soodanig te boek staat in de familie wenschen op te nemen. Dit geldt voor Dajaks zoowel als Maleiers; ook de Chineezen moeten van dat volkje niets hebben. Te Pangkalan Boen zijn twee stokoude vrouwen die in den reuk van hantoeën staan.

De kwalen, die ze verwekken, zijn doodelijk; ze kruipen 's nachts bij de slapenden, en zuigen hun het bloed uit. Ook pogen ze kraamvrouwen te hinderen. Een middel hiertegen is een net; hieraan hebben deze wezens nl. een grooten hekel, doordat in het grijs verleden eens één hunner, dien men betrapt had, in een net, dat men voor de deur had gespannen welke hij binnen moest, gevangen werd. Bij 't krieken van den dag moet de kop bij het lichaam terug zijn, anders zal hij sterven, daar hij niet bestand is tegen de stralen van de zon.

Talrijk zijn natuurlijk de verhalen die betreftende een en ander in omloop zijn. Zeer zwaar is de straf die, bv. aan de Katingan, bedreigd wordt tegen hem, die een ander zonder reden voor hantoeën uitscheldt. De boete daarop is drie tot zes djipen, welke boete men noemt Singer tandahan hantoeën. Zelfs indien hij alleen gedroomd heeft, dat de beklaagde hantoeën is, dan is dat nog niet voldoende om hem vrij uit te laten gaan, hoewel in dat geval toch de goede naam van den aldus betitelden een gevoeligen knak krijgt.

$\mathrm{Al}$ deze hantoeën hebben ook nog na hun dood de macht tot kwaad doen, zijn dan echter lang niet meer zoo gevaarlijk als bij hun leven. Evenals de kariau's onder Pampahilep staan, hebben de hantoeën een vorst nl: Radja haramaung batolang dohong, (de tijger koning, die dohongs tot botten heeft; een dohong is een oude tweesnijdende dolk meestal met ivoren handvat).

Indien men een hantoeën ter dood heeft gebracht, blijft het zaak hem goed uitgerust ten hemel te doen gaan, wil men niet na diens dood aan de wraak blootstaan.

Een ander gevreesd persoon is de Radja Poeroe (Ng.) of Radja Tjatjar (Koning pokken). Ook deze is van menschelijken 
oorsprong. Op zijn vele reizen ging hij tot het geloof over van zijn stiefvader, den eigenlijken Radja Tjatjar; hij werd Mohamedaan en woonde - naar de Saroejansche legende - aan de monding dier rivier. Op zekeren dag, toen hij weer op een zijner tochten was, ontmoette hij zijn familie, dewelke hij als teeken van verwantschap een steenen olifant gaf, waarbij verschillende menschelijke gestalten als panakawan dienst doen. Is nu de Pokken koning in aantocht, dan geeft de olifant een olieachtige stof af, die als obat geacht wordt. Men offert dezen olifant geregeld, en smeert hem met kippenbloed in. Varkensbloed is in verband met den godsdienst natuurlijk verboden.

Ik trof op mijn reizen twee zulke beelden aan nl. een in Pandau aan de Aroet en een in Rantau Poeloet aan de Saroejan. Beide worden zeer goed verzorgd. De Ngadjoe is van oordeel dat Radja Poeroe in een groot zwart schip woont, midden in zee.

Zijn dit de voornaamste geesten die men kent, talrijk zijn natuurlijk de min of meer plaatselijke spoken, wier beteekenis op het leven der Dajaks echter veelal nihil is. Men bepaalt zich tot het brengen van kleine offers ingeval men aan hun bestaan herinnerd wordt, bv. doordat men zulk een wezen in den droom heeft gezien, of hem in den nacht is tegengekomen.

\section{\$ 30. De tusschenpersonen tusschen hoogere wezens en mensch.}

Niet ieder burger is natuurlijk in staat op te treden als bemiddelaar tusschen mensch en hooger wezen, niet ieder kan zelfs in alle omstandigheden, die werkzaamheden verrichten, welke in zijn eigen belang gedaan moeten worden. De talrijke hoogere wezens worden over het algemeen zelfs niet door de bevolking gekend. Slechts geesten en spoken, alsmede eenige vooraanstaande Sangiangs, zijn bij een ieder bekend. Het is dus duidelijk, dat men voor de talrijke bezweringen zich moet bedienen van de hulp van ter zake kundigen de z.g.n. "priesters».

We zagen reeds in Hoofdstuk I, hoe ten aanzien der aanrakingen met de oerai, de hoofden der vestiging de aanroepingen doen, die noodzakelijk zijn. We zullen voorts hierna nog meerdere malen - vooral ten aanzien van Kota Waringin moeten wijzen op priesterlijke werkzaamheden der hoofden.

In verreweg het grootste gedeelte van Zuid-Borneo echter 
heeft men speciale middelaars in hoogere zaken, het zij dan dat de namen verschillen. Ook in Kota Waringin heeft men voor grootere bezweringen priesters noodig. Men noemt ze: balian (Ngd.) basir (Ngad.) bolin (K.W.) djaja (Sar.) (Sahiai).

Gaan we allereerst na hoe men tot dit ambt komen kan. Bij de Ngadjoe's treft men zoowel mannelijke (basir) als vrouwelijke (balian) priesters aan. In den tegenwoordigen tijd ziet men daartoe meestal bezadigde lieden, die de Godentaal ten deele machtig zijn, en op de hoogte van den Godsdienst zijn. Vroeger waren de mannelijke middelaars meestal hermaphrodieten, van daar ook hun naam; waren ze dit niet, dan droegen ze toch in elk geval vrouwenkleeren. Deze tweeslachtigen zijn niet alleen bij de Dajaks in hoog aanzien, ook de Bandjereezen beschouwen hen als hoogere wezens en als de tusschenpersonen bij uitnemendheid tusschen Goden en menschen, omdat deze personen afstammen van de Dewa's (tetoeroenan dewa).

Er wordt beweerd dat de tweeslachtigheid erfelijk is. Een hermaphrodiet zou kinderen kunnen verwekken, die natuurlijk ook tetoeroenan dewa zijn. ${ }^{1}$ ) Aangaande de balians weet men niet zulke teekenen te noemen, en ook lang niet elke als basir optredende persoon is dusdanig "bevoorrecht». De vrouwen waren oudtijds meestal mooie jonge slavinnen, die voor hun meesters dit winstgevend bedrijf uitoefenden, of het waren dochters uit aanzienlijke geslachten, die dit ambt uit teleurstelling in zake de liefde, dan wel om hun ouders onaangenaam te zijn, hiertoe overgingen. Want hoewel het ambt in hooge eere stond, en een beleediging de balian aangedaan, zwaarder gestraft werd, dan die de gewone lieden betreffende, zag men toch zijn zuster niet gaarne tot dit bedrijf haar toevlucht nemen. Immers behalve priesteressen waren het tevens vrouwen van ontucht, en nu mag het zijn, dat de Dajak het met de zedelijkheid niet zeer nauw neemt, het zich aan een ieder verkoopen, acht hij toch minder oirbaar. Het is dan ook niet te verwonderen dat we een strafbepaling aantreffen aangaande het overhalen van een meisje om balian te worden. De verleider wordt dan gestraft met één tot vijf djipen (à $f 30 .-$ ).

1) $\mathrm{Bij}$ besnijdenissen, en ook bij het oogstfeest der Bandjereezen, is nagenoeg steeds een basir aanwezig, die daarbij een hoofdrol speelt.

Behoudens hun heiligheid, leenen zij zich tevens tot ontuchtige handelingen, die mede een ruime bron van inkomsten voor hen doen vloeien. 
Indien vroeger een balian trouwde, legde zij haar ambt neer, tegenwoordig echter zijn ze bijna alle getrouwd.

Aan de Katingan heeft men echter, zoowel voor het mannelijk als vrouwelijk geslacht, als ware priesters slechts "geroepenen»; ook de Kota Waringische bolin volgt zijn roeping. Op een zekeren dag krijgt hij een droom of ander teeken, dat hij zich aan het priesterlijk ambt moet wijden, waarop hij zich in het bosch afzondert en daar soms maanden, ja zelfs jaren, vertoeft.

Terugkeerende zijn ze priesters en meestal in het bezit van talrijke hun door de Goden gegeven heilige steentjes en stokjes. Want in oogenblikken van extase, in het bosch - wellicht door de ontbering - meegemaakt, vermeenen zij met de Goden zelve verkeer gehad te hebben.

Het komt echter ook voor, dat de geroepene niet geroepen blijkt te zijn en verschillende personen keeren terug uit het bosch, zonder ander resultaat, dan dat ze krankzinnig of malende zijn. Zoo is aan de boven-Katingan en in Kota Waringin menige kampong-gek op die wijze tot zijn ongeluk gekomen. Ook deze lieden staan, tot op zekere hoogte, in reuk van heiligheid en behoeven zich voor hun levensonderhoud geen zorgen te maken.

\section{$\S 31$. De werkwijzen der priesters.}

De balian pleegt niet alléén te werken, maar, al naar gelang van de belangrijkheid van het werk, met drie, vijf, zeven of een ander oneven aantal helpers. De leidende persoon noemt men oepoh (Ngad.) of poei (Sahiai), de helpers zijn de panompah (Ngad.) of pengapit (Sahiai). Het eigenlijke werk wordt door de eersten verricht, de laatsten verklaren slechts het gebeuren, of zingen de te herhalen zangen.

Er bestaat eenig verschil in de wijze van werken der priesters in de verschillende streken. Ziet men bij de Ngadjoes de extase, waarin de oepoh moet verkeeren, verwekt worden door trommel (katabing)-slag, aan de boven-Katingan heeft dit middels schommelen en reukwerk plaats. Deze bewerkingen noemt men: njankei.

Het geval zit nl. zóó, dat de priester(es) zelf geenerlei macht heeft met de Goden te verkeeren, als hij (zij) niet in dezen toestand (marau hingat) is. Ze heeft daardoor de gave dat de aan te roepen Sangiang haar lichaam binnen gaat en daar de plaats van haar ziel inneemt. Deze laatste nu gaat als dit gebeurt naar de woonplaats der Goden, om aldaar de hulp dier 
wezens te verkrijgen; zij maakt daarbij gebruik van het lichaam der Sangiang, die haar dit welwillend heeft afgestaan. Daartoe moet dus eerst de Sangiang worden opgeroepen (nimang Sangiang, nimang $=$ roepen). Daartoa moet rijst gestrooid worden op een manier die we hieronder nader zullen zien.

Alvorens echter over te gaan tot het oproepen der geesten, wordt allereerst het tantoelak (afweren) gehouden, hetgeen dient om eventueel aanwezige kwade geesten te verdrijven.

We zullen later de bezoldiging der priesters(essen) kunnen nagaan. Bij de verschillende gebeurtenissen nu hebben we te doen met afwijkende ceremoniën, die zoowel in vorm als in lengte sterk afwijken. Behalve bij het voldoen van beloften, het vragen van geluk of van een lang leven, en al dergelijk soort van zaken meer, is het ook een plicht dezer priesters om na te gaan, door welke redenen een mensch ziek is geworden, en de middelen te beproeven om de zielestof of wel de weggeloopen ziel terug te bekomen. Men heeft nu ook eene categorie godendienaren die zich slechts met deze laatste gebruiken bezighouden, en daarbij veelal ook geneesmiddelen van meer waarde uitdeelen. Men zou deze meer met de Maleische doekoen kunnen vergelijken, zij dragen echter den naam oloh dewa (Mal. orang dewa). De Maleiers hebben toch naast hun doekoens evenzeer deze dansende en zingende geneesheeren. Bij de Ott Danoems was ik eens getuige van zulk een genezing door een oloh Sangiang (een afstammelinge der Goden); men noemde dit feest "haralioeng". Een meisje was een weinig malende en moest genezen worden. Daartoe had men van waringintakken een zoogenaamde pohon loenoek.gemaakt, waar men in steeds sneller tempo omheen danste (narai); toen de patiënte duizelig werd, werd ze op den grond gezet en de ziekte veroorzakende steen werd uit haar hoofd gehaald (ngakoi), en daarna werd ze met een kwast jonge pinangvruchten (manjang) over het hoofd gestreken (malitai). Het eind was dat de jonge vrouw in slaap viel. Dit feest duurt drie dagen. De eerste dag is het tantoelak, de tweede het boven beschreven narai, de derde laat men een maskerdans doen ter afschrikking der booze geesten en laat een nagemaakt scheepje de rivier afdrijven, of hangt het in een boom, nadat de patiënte op het voorwerp gespogen heeft. De "priesteres» die het feest leidde, was er een van den tweeden rang. De hoogste klasse der balians vormen, evenals 
bij de Dewa's, de oloh mahiting, de tweede categorie zijn de oloh ngakai; de laagsten, die slechts kleine bezweringen houden of lichte kwalen genezen, zijn de oloh njanda.

In den toestand van extase nu krijgen de balians de hulp der hoogere wezens, om de schuilplaats der gevluchte ziel op te sporen, die dan meteen in de godenwoonplaats met geneesmiddelen behandeld wordt. Dan wel men neemt van daar zaken mede, die dienstig kunnen zijn aan de genezing nadat men de ziekte der ziel veroorzakende voorwerpen, als splinters, steentjes enz. uit het lichaam der lijders heeft verwijderd.

Alvorens de toestand van extase wordt bereikt, heeft men eerst zorgvuldig in een doekje eenige heele rijstkorrels gelegd, wat een teeken van terugkeer van de afwezige ziel der balian is; als deze rijstkorrels gebroken blijken te zijn bij opening van het pakje, wordt de balian met bloed bestreken (manapas, moepas, manjaki), waarna ze weer tot het gewone leven terugkeert.

Zeer bekwame balians kunnen op die wijze ook inlichtingen geven over waardevolle zaken die bv. zoek zijn geraakt, ze kunnen de plaats waar ze zich bevinden aanwijzen. ${ }^{1}$ )

Behalve dat de balians zich dus leenen tot hun godsdienstig bedrijf en de ontucht, zijn ze ook zeer gezocht om hun zangkunst; heele nachten kan de Ngadjoe naar de heldendichten van Tempoen Telon, Sangoemang of Bandas bin Toemenggoeng luisteren en genieten van de grootendeels onbegrijpelijke Sangiang taal. Veelal is zulk een avond een inleiding tot een orgie, want nog niet zoo heel lang geleden waren de Ngadjoe's vooral berucht om hun feesten.

We zullen later nog kennis nemen van verschillende gelegenheden waarbij hun hulp wordt noodig geacht, en thans overgaan tot de behandeling der meer bijzondere gebeurtenissen die aanleiding geven tot balian-feesten.

\$ 32. Algemeene mededeelingen over de priesterlijke werkzaamheden.

We onderscheiden in de eerste plaats twee soorten balianfeesten en wel die, waarbij een of meer sawangboompjes worden

1) Iets dergelijks zijn ook de doekoen hintan uit het Martapoerasche, alvorens men een nieuwen put gaat aanleggen, zal men zulk een persoon in den arm nemen. Hij weet $\mathrm{nl}$. waar zich diamanten bevinden. Men betaalt voor zulk een consult gewoonlijk tien gulden. Treft men niets aan, dan is dat natuurlijk een gevolg van het niet houden der palivoorschriften. 
gebruikt, met de daarbij behoorende lieden, de zgn. taras sawang (merg der sawang), die gedurende het feestvieren niet mogen slapen. Ze behoeven geen balian te zijn. De tweede categorie is die, waarbij geen sawang's gebruikt worden. Dit is geen onderscheiding in groote en kleine zaken, maar een in zaken, die betrekking hebben op de toekomst, en die, welke voor het oogenblik gelden, of inlossingen zijn van beloften. De gebruikte sawang wordt gepant, en de wijze van groei daarvan wijst aan in hoeverre aan de wenschen is voldaan. In geval zulk een boompje een kwijnend bestaan voert of dood gaat, is dit een teeken dat de goden niet wenschen te voldoen aan het verzoek, dan wel dat het feest niet voldoende geweest is. In beide gevallen zal men nogmaals tot hetzelfde feest overgaan.

Het spreekt van zelf dat, in geval de hulp der Sangiang wordt ingeroepen voor een af ander, men zich zal moeten bedienen van hun taal "talatai pangentang" (talatai $=$ raad, overleg, pangentang $=$ offerfeest, het zou vrij vertaald kunnen worden $:$ hetgeen wat men te doen heeft om een offerfeest te doen slagen). Bij die feesten waarbij geen sawang gebruikt wordt, behoeft men ook geen basa Sangiang te gebruiken.

Beide soorten van feesten worden slechts 's avonds en 's nachts gehouden. We zullen thans zien welke feesten onder beide categorieën zijn onder te brengen.

\section{a. Geen sawang.}

1. Tantoelak (of weren van booze invloeden).

2. Meloepoet hadjat (inlossen van eene belofte aan de hoogere wezens gedaan).

3. Mampendeng karamat (het opstellen van een offerhuisje ter inlossing van een belofte).

4. Menambang Sahoer (het opstellen van een offer ingevolge belofte, menambang $=$ inhalen).

5. Balian Karahan (het feest waarbij rahan (of balai) opgesteld wordt).

6. Balian hai paloes harahan (het groote balian feest, gevolgd door het opstellen van een rahan).

7. Balian hai (het groote balian feest) zonder dat een rahan wordt opgesteld. In dat geval eindigt de balian hai met een manjakai der aanwezigen. Daarbij worden tingang-veeren en bladen van de Palas die op een bijzondere wijze gevlochten 
zijn (sangkai) gebruikt als middelen om het bloed op de lichamen te brengen. Daarom noemt men dit feest ook wel "hatinggang hasangkei».

8. Balian hamihing (mihing $=$ een soort offermand) een feest waarbij men een mihing opstelt midden in het dorp met den voorkant naar de oeloezijde. Bij zeer goede oogsten pleegt men wel zulk een feest te vieren.

9. Mampencleng hoeman oentoeng: een offerhuisje gewijd aan Radja Oentoeng opstellen.

b. De feesten waarbij een sawang geplant moet worden zijn de volgende:

1. Manjaki $=$ met bloed bestrijken.

2. Mamboehoel masah $=$ bezweringen om de ziel van een zieke terug te krijgen, om hem aan het lichaam te knoopen.

3. Mamboe sawang kajoe, ook wel blakoe tahaseng (adem vragen) geheeten, evenzoo een bezwering met zieken te verrichten en bij huwelijk.

4. Mampandoi, het eerste bad der kinderen in de rivier.

5. Mambong karoehai, het bezweren der toovermiddelen. Willen deze karoehai hun goede werking blijven behouden dan moet te hunner eere af en toe een feest gegeven worden.

6. Blakoe oentoeng parei, het verzoeken van een goeden oogst.

7. Blakoe oentoeng, het inroepen van Radja Oentoeng's hulp voor alle andere aangelegenheden.

8. Mamoengkal oentoeng, het verzamelen van het geluk (hetzelfde als $\mathrm{N}^{\circ}$. 7).

9. Blakoe toetoeng oentoeng (het geluk bestendigen).

10. Blakoe toentoeng poesoer (beide tot het verkrijgen van

11. Blakoe toentoeng tahaseng een lang leven.

12. Mandjoeng ganan blanga hajah mambang karoehai (de ziel der blanga's naar boven sturen om den toovermiddelen nieuwe kracht te geven).

13. Mandjoeng ganan halamang enz. idem met de ziel der halamang.

Gaan we thans na in hoever deze feesten van elkaar afwijken:

$$
\text { §33. Tantoelak. }
$$

Al de hierboven genoemde werkzaamheden moeten vooraf gegaan worden door de eerst genoemde bezwering, het tantoelak, 
het weren der booze geesten. Er zijn echter ook gebeurtenissen in het leven die men doet volgen door een tantoelak. In dat geval heeft het de bedoeling de onder invloed dier gebeurtenissen wellicht ontstane kwade invloeden te keeren. We onderscheiden:

1. Tantoelak hoeang kahapoes palin oloh babana masawa. Het tantoelak ter beëindiging der verbods periode om den coitus uit te oefenen. Dergelijke palitijden heeft men bv. bij toewah feesten, bij zwangerschap en in sommige streken bij de eerste dagen van het huwelijk. In dit geval moet men beginnen met de betrokken personen met bloed te bestrijken. Hebben ze echter reeds vroeger gemeenschap gehad - hoewel dat niet mag volgens de adat - dan moeten ze tevens het mamboehoel masak (tot vastknooping hunner ziel) houden. Ook voegt men nog wel een mambong karoehai aan de plechtigheid toe. Zou men een en ander niet in acht nemen dan zou het gevolg daarvan zijn een verwekken van kinderen, die niet slechts van menschen afstammen, maar mede van de kwade geesten die men verdrijven wil.

2. Tantoelak doehi, na bezweringen, welke dan ook (doehi $=$ doorn, ook kwade invloed); het is een ceremonie, die men na elke der bovengenoemde plechtigheden pleegt te houden. Men neemt daartoe een grooten rotan-slinger met doorns er aan, die door een geslepen bamboe getrokken wordt; zooals de doorns daar afvliegen, zoo zullen ook de kwade invloeden wijken van den mensch.

3. Tantoelak basin bari, te houden na het tiwah-feest (doodenfeest), (basin bari $=$ bedorven rijst).

$\mathrm{Na}$ het doodenfeest wordt met zure rijst de plaats, waar het lijk in het huis gestaan heeft, gereinigd om de laatste sporen weg te nemen, daarmee wordt tevens geacht dat de smart der nabestaanden wordt weggenomen. In Kota Waringin gaat een en ander anders toe. Men reinigt daar de plaats, waar de balai hantoe (karonda) heeft gestaan met water, toewak en kurkuma gemengd met klapperolie, zoogenaamd om de laatste teekenen van het verblijf der dooden op aarde weg te nemen.

4. Tantoelak voordat iemand "gemanjakied» wordt, die van elders komt. Het beste neemt men dit gebruik nog waar in Kota Waringin, waar de vreemdeling, zooals reeds in $\$ 23$ werd meegedeeld, een heel ceremonieel heeft door te maken als hij in een andere plaats komt. Behalve de reeds vermelde ceremoniën, kan daar nog een en ander aan worden toegevoegd. 
Komt men per prauw in de Boelik dan wordt men aan de batang van het Hoofd opgewacht, en eenige priesters (bolin) bestrijken de reiziger van het hoofd tot de voeten met een kwast jonge pinangvruchten (majang), hetgeen manoelak genoemd wordt. De eventueel in andere streken opgeloopen kwade invloeden worden daardoor verjaagd; behoudens dat dit voor de reizigers zijn voordeel heeft, is dit tevens nuttig voor de te bereizen streek, die daardoor geen overlast zal ondervinden van eventueel meegekomen kwade geesten.

5. Het tantoelak na den dood; dit heeft ten doel de ziel van den afgestorvene, die tot het tiwah-feest voor een deel op aarde rondzwerft, op een behoorlijken afstand te houden. De nabestaanden moeten dan tevens het mamboe sawang kajoe houden. We zullen later meer uitvoerig van deze doodengebruiken melding maken.

6. Het tantoelak alvorens men het manjaki houdt voor het betrekken van een nieuw huis. Indien men dit huis betrekt, moet men nl. deze woning met bloed besmeren(manjaki hoema), bij dit groote feest worden de kamponggenooten genoodigd. Het manjaki heeft overdag plaats met varkensbloed, tevens wordt dan een klein huisje opgesteld, een z.g.n. sakei nai (voor het bestijgen), om als vergoeding te dienen voor hun verwoeste huis (de grond). Ook dit miniatuur huisje wordt "gemanjakied».

Alvorens nu daartoe over te gaan wordt eerst een tantoelak gehouden om, indien de sambalik reeds mochten zijn gevestigd in de nieuwe woning, deze daaruit te verdrijven. Zou men dit feest niet geven, dan zou men door zware koortsen die evenzoo sambalik heeten worden geplaagd; ook hantoeën kunnen deze ziekte veroorzaken, maar in hoofdzaak zijn het de sambalik zelve, zooals trouwens ook blijkt uit den naam.

$\mathrm{Bij}$ het manjaki moet men tevens «Manboeng Karoehai».

7. Tantoelak voor doortrekkende reizigers, hetgeen hetzelfde is als sub. 4 genoemd, echter de strekking heeft de geesten uit het ressort op behoorlijken afstand van den reiziger te houden, in verband met de aansprakelijkheid van de kringleden voor hun gast.

8. Tantoelak sial. Indien iemand zich door een of anderen kwaden geest bezeten acht, kortom als hij meent in een toestand van sial te zijn gekomen (bv. een muis zit in zijn matras of heeft een gat in zijn klamboe gebeten), dan houdt men een 
tantoelak. Dit kan echter alleen maar gebeuren door een lid der familie zelve; indien anderen zulks doen, heeft dat geen nut. Is er in die familie niemand ter zake kundig, dan moet men een grootere bezwering doen geven, dan wel volstaan met het geven van eten aan den sial verwekkenden geest.

Al deze sial verwekkende invloeden staan onder leiding der reeds genoemden Radja sial.

Een ongeluksteeken is tevens als vogels binnen komen nestelen; ook deze verjaagt men door hen op een antjah (offermandja) eten te geven.

Zooals we reeds zagen, moeten nagenoeg alle bezweringen door het tantoelak voorafgegaan worden. Er zijn er echter eenige waarbij dit niet noodig is en wel voor het mambohol manta of nangkadja andau. Dit zijn de zeer korte plechtigheden (nangkadja $=$ voor korten tijd), waarbij men slechts een weinig eten aan de geesten geeft; in dit geval wordt slechts één kip geslacht.

Gaat men om te offeren naar de graven der afgestorvenen, dan noemt met dat offer "basasangka». Ingeval drie hoenderen geslacht worden, is het feest een "baramanja»; voor een zwijn is de naam manjanggok. Offert men slechts rijst met ei dan heet zulk offeren manimbal.

Het angkadja andau is niet bedoeld voor de Sangiang of de geesten, vandaar dat het tantoelak niet noodig is; het is ten bate der voorteeken-vogels, en wel in het bijzonder voor de antang (kiekendief).

Men plaatst daartoe een rahan en spreekt dan van antang darahan; gebruikt men een basir om de bezwering te houden dan is tantoelak noodzakelijk. Vrouwen mogen bij deze bezwering niet behulpzaam zijn. Vóór het offer neer te zetten strooit men rijst. We zullen bij de behandeling der voorteekenen hier nader op terugkomen.

Verder is bij het manawoer het doen van een verzoek aan de antang, om antwoord te geven op een bepaalde vraag het tantoelak niet noodig. Men heeft zelfs geen balian te gebruiken. Zoo ook ingeval iemand is overleden; dan strooit men buitenshuis gele en roode rijst om de ziel der afgestorvenen weg te lokken. Ook daarbij maakt men geen gebruik van een balian, die verricht haar diensten eerst den volgenden dag bij het tantoelak der dooden (Zie boven No. 5.). 


\section{\$34. Maloepoet hadjat.}

Men kan aan een verzoek, tot de hoogere wezens gericht, een belofte verbinden, om, als het gevraagde wordt gegeven een feest te hunner eere te geven, dat zóó en zóólang duren zal, en waarbij dit en dat geslacht zal worden. In geval dan de belofte moet worden nagekomen, aangezien de goden den wensch hebben vervuld, pleegt men het dan te geven feest, waarbij zooveel balians moeten werkzaam zijn, als destijds beloofd is, maloepoet hadjat (het inlossen der belofte) te noemen. Men kan de belofte ook zoo inkleeden, dat men den Goden van al het ontvangene iets toezegt. In dat geval behoeft het getal der te slachten dieren en der te bezigen balians, niet genoemd te worden.

Het allereerste, waartoe men overgaat bij het maloepoet hadjat is het ophangen van een mihing (offermandje) binnenshuis boven de deur. Daarin wordt het te gevene neergelegd; het behoeft natuurlijk geen betoog, dat hoogere wezens slechts de essence der gift genieten.

Men pleegt zulke beloften meestal ò aan Sangoemang òf aan de Djata's te doen. In het eerste geval brengt men het offer in een boschje, waar hij vereerd wordt, in het laatste hangt men een antjak bij een diepe bocht van een rivier (labehoe, to'ok) op, en spreekt daar den wensch uit. Bij vervulling is het feest thuis, waar op genoemde plaats dan een offerhuisje opgericht wordt.

In geval van gewone verzoeken offert men aan den Sangiang, die bij overlevering aan de familie steeds goede diensten heeft gedaan, en daardoor, om zoo te zeggen haar schutsheilige is geworden.

Gaan we thans na hoe het maloepoet hadjat plaats heeft.

Als voorbeeld zal ik het maloepoet hadjat (nipasahoei) der Sahiai Dajaks der boven Katingan beschrijven, aan de hand van de kaart die een oude balian, Pait genaamd, mij afstond en die de woonplaats der Sangiangs voorstelt.

Het feest in kwestie duurt vier tot vijf dagen, of liever gezegd nachten. In het midden van het huis, waar het feest gegeven zal worden, wordt allereerst een nagemaakte boom opgericht van loenoek-takken. Men noemt deze «loenoek» of zooals de Ngadjoes zeggen "periwajak». 
Zoodra de hoofd-balian door de muziek der tatambong en het schommelen, in de positie marau hingat gekomen is (zie $\S 31$ ), is dit een teeken, dat de Sangiang, die geroepen is, bezit van haar lichaam heeft genomen, en dat de balian-ziel zich op weg gaat begeven.

Alvorens de zitting echter is begonnen, is manjan gebrand (welriekend hars), en een weinig rijst door de hoofd-balian omhoog geworpen. Deze rijst draagt den naam «behas mering penjang. Vlak boven de aarde nl., even boven onze hoofden, is het einde der hemelsche rivier, welke uitmonding men Toembang Batang Danoem Hinting Sangiang noemt. De gana (ziel), van de rijst gaat dan naar lewoen Sangiang, de woonplaats der geroepene en brengt aan de hoogere wezens het verzoek over, om hulp te verleenen. De ontboden Sangiang begeeft zich dan naar de aarde, met het schip "talawang», een schip in den vorm van een pinangschede, dat getrokken wordt door den tingang (de neushoornvogel). Moet echter de Sangiang van verre komen, heeft men dus een der voornamen opgeroepen, dan maken ze gebruik van het groote schip, de zgn. "banama tingang». Dit schip laadt alles wat men wil, het is nooit te klein en kan een geweldige snelheid bekomen; het is gebouwd in den vorm van een tingang-vogel. (De Ngadjoe's noemen de beide schepen anama brohong en b. tingang).

Alleen de Sangiang uit de hoogste afdeeling van lewoen Sangiang komen niet persoonlijk naar beneden, maar sturen een ander, die den oproeper tot hen zal voeren. Zoodra nu de Sangiang de balian-ziel in zich heeft opgenomen, vangt de reis aan. De helpsters bezingen de avonturen, die onderweg beleefd worden, daartoe geinspireerd door de Sangiangen-ziel, die in de hoofd-balian is gevaren.

De feestgever wordt dan allereerst bestreken met sawangbladeren en danoem roeang (dit is water dat men uit een prauw geschept heeft), welke bewerking "moepas» heet. Daarop wordt hij met het bloed der geslachte dieren "gemanjakied», en daarna gebaad (moenoes). Dit alles dient om het sial van hem af te wenden.

De Sangiang vaart nu de rivier Rahoesan op, zonder zich $o p$ de heenreis te bekommeren om de zijrivieren, die hij voorbij vaart; zoo komt men in lewoe ain Kameloeh tahoetoen Sakai Hawon. 
De eerste vestiging dus in de Tasik Hawon (de nevelzee) die zich onder de eigenlijke godenwoonplaats bevindt. Kameloeh voert hier het bestuur. Hier vraagt men voorwerpen om ziekte te bestrijden of anderszins en gaat daarna verder.

Een nieuwe moeilijkheid op den weg is de z.g.n. Njaring sapoendoe hinting; d.w.z. de brug (hinting), die door de Njaring gesteund wordt. Deze brug bestaat uit twee deelen, aan de eene zijde gaan de gana's der opgeworpen rijst, aan den anderen kant vaart het Sangiang-schip. Na dit volbracht te hebben, gaat men even aan bij de "Tandjoeng Hawon baragana Harimaoeng baboeloe boelau, tinai djaliwan boelau, (de nevelbocht, bewoond door den tijger met de gouden haren en de gouden slang).

Hier wordt een weinig adem (tahaseng) ingenomen, waarop men de Laoet Hawon binnenvaart die van de Tasik Hawon middels een doek - de "kain Timpoeng" - is afgesloten. De gana's der gestrooide rijst hebben echter deze afsluiting reeds geopend voor de komende boot, zoodat geenerlei belemmering wordt ondervonden, hoewel men voordien toch nog vergunning heeft moeten vragen aan den wakenden tijger.

Zoo komt men aan Toenggang (Toembang) Langit, welke is afgesloten door de "Garing kanata hintan» (de garingboom, die bezet is met diamanten). Vlak hierbij ligt de woning van den bewaker dier poort, zijnde dit de «Bakai Boelau, inggalar Toemenggoeng Radja Tiwoeng» (de gouden aap getiteld Toemenggoeng Radja Tiwoeng). Niemand, zelfs niet de Sangiangs, kunnen hem passeeren zonder vergunning verkregen te hebben. Aangezien deze waker verzot is op pisang en suikerriet, geeft men hem die ten geschenke, in ruil voor de vergunning.

Zoo is men dan in de eigenlijke lewoe Sangiang aangekomen en doet daar allereerst lewoe balai aan, welke uit twee vestingen bestaat nl., Toembang Baras boeroeng en Lawang Baras; men noemt deze peisterplaats ook wel Lewoe Rakei Njahan. Bij deze kampong moet men aanleggen, zoowel ingeval men stroomop als stroomaf gaat. Wil men toch verder gaan, dan zal men van de banama Tingang moeten gebruik maken; deze wordt bestuurd door zekeren Toemenggoeng Mai Pandoeng, een Sangiang afkomstig uit lewoe Kamanda, ook een der vestigingen, die Lewoe Rakei vormen.

Men begeeft zich thans naar de Lewoe Sangoemang, die aan de zijrivier "Batang Danoem Rendjek penjang" is gelegen, en die 
bewoond wordt door den grooten Sangiang Sangoemang, die hier mede den titel draagt: Radja Toekei Tamboeh Laoet. Men noemt zijn rijk Radja Ott Rasoek Samboeng. Hier, zoowel als in Lewoe Sahawang, aan dezelfde rivier gelegen, krijgt men allerlei voorwerpen, noodig om een blakoe oentoeng te houden en te doen slagen. Tevens kan men nu, met Sangoemangs hulp, doordringen tot in den top des hemels, het z. g. n. Pangenan awi Rendan Hawoerang Hintan. Daar wonen de Sangiangs: Roemba Djaja Sangiang menda Langit en Dara Sangiang Nambit toendoen Langit. Wat zij zeggen in te zullen willigen, gebeurt. De gana's der rijst gaan niet zoo ver; deze kunnen tot dit heilige der heiligen niet doordringen, maar eindigen hun tocht reeds eerder.

$\mathrm{Nu}$ kan men naar den Loenoek-boom afzakken, waar vandaan men allerlei geneesmiddelen en djimats haalt, om bestendige gelukzaligheid te verkrijgen. Deze wonderboom heeft vruchten die deels rijp zijn, deels half rijp; soms staat de boom nog in bloei. Het is van hier, dat alle geneesmiddelen moeten komen.

Men steekt nu de hoofdrivier over en gaat naar de zeven teloks, in elk waarvan een waardevolle watersoort te vinden is. Het zijn achtereenvolgens:

1. Danoem Hambit - het gebruik waarvan uwe wenschen zal vervullen.

2. Danoem Sambelom - levenswater.

3. Danoem Toeak - dat gebruikt moet worden bij elke bezwering.

4. Danoem Oentoeng - waarvan het gebruik geluk zal brengen.

5. Danoem Bambang Penjang - water, dat voor allerhande zaken goed is, speciaal dienend voor een bestendige gezondheid.

6. Danoem Sakaritan - dat als tantoelak sial gebruikt wordt.

7. Danoem Kahiringen - het levenswater.

Heeft men van al deze watertjes een weinig meegenomen, dan vertrekt men weer naar de bergen Boekit Manahoi Dohong en Boekit Tantan kering Roendjan, beide gelegen aan de Batang Danoem Dereh Boelau. Door deze rivier op te varen kan men echter het doel niet bereiken, maar moet daartoe de antassan nemen. Op deze bergen snijdt men met een dohong een weinig hout dat als nikat (djimat) dienst moet noen. 
Is dit volbracht, dan keert men terug en verlaat den hemel. In de tasik tamboen bangau bagawing boelau (het meer van de zeeslang met de reigerhals en gouden tanden) worden de voorwerpen, die meegebracht zijn, gewasschen. Men komt in dat meer door de Batang Danoem Sangkalila Boelau (de goud bloeiende rivier). Zoodra nu de ziel der hoofd-balian blijkt te zijn teruggekeerd (zie $\S 31$ ), wordt de feestgever "gemandied, en "gemoepasd» met de meegebrachte zaken, en worden hem de djimats ter hand gesteld. Het is begrijpelijk dat de Sangiang niet voor niets geholpen heeft, men geeft hem dus zijn loon en wel: een gantang poeloet (kleefrijst), een gantang padi, een bord, een kom, een agaatkraal en een parang om zijn ziel te versterken (takang hambaman); voorts nog een doek als sapau banama (dak voor het schip) en twee lalangs (nieuwe potten) als soewang banama (lading voor het schip).

Natuurlijk neemt de Sangiang ook hiervan slechts de essence, en hetgeen resteert is voor de balians. Verder ontvangt de hoofd-balian als haar loon; een djipen; de helpsters elk een blanga (pot) van $f$.- waarde.

Wordt een bezwering slechts gehouden, om een weggeloopen ziel weer op te vangen, dan vaart men maar tot de Talaga die de oorsprong vormt van de Sakai Hawon; daar zoekt men de ziel en baadt deze direct in hetzelfde meer. Men gaat dan naar het bovengenoemde meer en baadt nogmaals de ziel; daarop terugkeerend bezoekt men de Boekit Batoe Sambang die bewoond wordt door de Sangiangs Pandoeng en Tahoendjoeng. Hier groeien tevens de roode sawang en de niboeng, wier doornen aan elkaar geprikt zijn, als waren het armbanden van dohongs; van deze beide schraapt men een weinig af, dat als djimat geldt. Maakt men deze reis, dan is het loon voor de balian slechts $f 2.50$, en is de kwestie in een avond afgeloopen. Gaat de tocht slechts tot Boekit Batoe Sambang dan is de prijs $f$ 1.-

We hebben dus gezien hoe de voorstellingen der Dajaks zijn ten opzichte van hun godenhemel; we hebben tevens opgemerkt hoe zij den mensch kunnen bijstaan in de vervulling zijner wenschen. Ten overvloede zij hier vermeld, dat nagenoeg elke rivier haar eigen voorstelling maakt van deze hoogere wereld, en dat de balians dier bevolking ook allen afzonderlijke kaarten bezigen, meestal op planken geschilderd en min of meer fraai afgewerkt. 
§ 35. Mampending Karamat.

Indien men een belofte heeft gedaan tot opstelling van een offerhuisje, moet bij die belofte zijn vastgesteld hoelang het feest duren zal, en moeten de te slachten dieren opgenoemd zijn. Men plaatst zulke huisjes meestal in een pahewan of een tadjahan (zie beneden), of men plaatst ze tegenover een labehoe. De opstelling gaat gepaard met een feest, dat nagenoeg gelijk is aan het maloepoet hadjat.

\section{$\S 36$. Manambang $\mathrm{Sah}$ oer.}

Voor dit feest, dat evenzeer een inlossing is van een belofte, moet een varken of karbouw geslacht worden; de duur van het feest is $2-3$ dagen. De eerste nacht wordt besteed aan het tantoelak. Den tweeden en derden nacht worden de voorbereidende zangen gehouden, die geleerd zouden zijn aan het volk door maharadja Sangen. Is een en ander gereed, dan wordt het huisje opgesteld waarbij wederom een dier geslacht wordt. De kop van het dier moet cvrijgekocht worden (manenga tewoes), waartoe de gasten een geschenk krijgen. Dit offer wordt geacht zeer goed te werken tegen benadeelende sambaliks; men noemt het daarom ook wel "Batang Mahaga», d.i. het eerbewijzen (aan de geesten).

\section{§27. Balian Harahan.}

Dit is een groot, feest meestal balian barampa rampar geheeten, dat drie tot zeven nachten duurt, en meestal inlossing is van eene belofte om kinderen te krijgen. Het is daartoe noodig een rahan op te richten, een soort balei, waarin de balians gedurende het feest plaats nemen. Hebben we echter te doen met een belofte aan de Djata gedaan, dan moet de rahan in het water worden opgesteld, waartoe men eerst een vlot makt; de rahan heet dan rakit rahan. In andere gevallen plaatst men veelal de rahan in heilige boschjes, soms in de kampong zelve. Behalve voor het verkrijgen van kinderen kan men dit feest slechts houden voor herstel van een zware ziekte, of voor het verkrijgen van een blanga. Ten aanzien van andere verzoeken kan men bij inwilliging dit feest niet doen houden.

Heeft de belofte tot het houden van een balian harahan niets uitgewerkt, dan kan men een balian hai, gevolgd door een 
harahan, beloven. In geval de wensch vervuld wordt geeft men een feest van zeven tot een en twintig nachten; voorts moet in huis zijn opgesteld: een pisang tangga, d.i. een pisangtros in een gong met rijst gezet, terwijl ook een rakit lamiang moet aanwezig zijn. Elken nacht moeten de balians zich met hasandah bezig houden. ${ }^{1}$ ) Voorts mogen de balians van kamponggenooten en vreemdelingen geschenken vragen, die het niet behoorlijk zou zijn te weigeren, en ten slotte moeten ze dagelijks den feestgever "mandiën», en met het bloed der geslachte dieren bestrijken.

\section{§ 38. Balian $\mathrm{Hai}$.}

Voor het balian hai is noodzakelijk dat men in huis heeft: tingang veeren en gevlochten palasbladen (sangkei), die dienst moeten doen voor het manjahi. Verder moet er een palangka zijn, die kan rond draaien. Zulke palangka's zijn offerplaatsen, bestaande uit een met naga's enz. beschilderden houten bak, omgeven door kains; ook het dak van het zoo ontstane huisje wordt door een doek gevormd. Ze staan òf op vier bamboepalen, ò op één - zooals in dit geval - ; soms ook hangen of staan ze op den grond. De palangka's worden geacht de woningen te zijn voor de helpende Sangiang. Bij het doodenfeest bv. is deze voor Rawing Tempoen Telon. Daarvoor zijn allerlei zaken ten nutte van Sangiang's en menschen opgesteld, zooals we straks zullen zien. In de palangka en aan de palen hangen eetwaren en versnaperingen voor de Sangiang. Tevens moet een balai voor de balians worden opgericht, nl. de balai sanggar, waaronder eenige lieden als wakers plaats nemen.

Ook moet een voorraad suikerriet aanwezig zijn, en verder allerlei van hout of papier vervaardigde dieren en naga's. Dit werk dat van één tot zeven maanden duren kan vereischte van de balians dezelfde verrichtingen, als die, welke bij $\S 37$ vereischt werden.

Behalve de verbodsbepalingen, die voor de andere bezweringen gelden heeft men hier tevens nog: 1 . het verbod om, als iemand

1) Sandah is een slavin van Tempoen Telon, die de rol ran clown vervult; talrijke grappige streken zijn van haar bekend, die men 's avonds in gezelschappen door balians laat voordragen. Men noemt deze bezigheid "hasandah". De verhalen zijn in een verbasterde Sangiangtaal gesteld, zoodat de toehoorders den loop der geschiedenis kunnen volgen. 
een ander een klein kind aangeeft om dit even vast te houden, zulks te weigeren.

2. Kleine kinderen los te laten rondloopen. Het eerste is verboden omdat dit feest gehouden wordt voor de verkrijging van kinderen, en deze handeling door sympathetische bezwering er toe zou leiden, dat geen kind gegeven wordt. De laatste verbodsbepaling geldt het verhinderen dat het kleine kind wegloopt, en daardoor denzelfden kwaden invloed zou te voorschijn roepen. $\mathrm{Na}$ afloop heeft het met bloed bestrijken plaats, waarna de tingang en sangkei in een boom worden opgehangen.

\section{§39. Balian Hamihing.}

Dit feest duurt zeven tot een en twintig nachten. Daarbij moet men de volgende zaken in acht nemen. 1. De balians moeten den ganschen nacht doorwerken en mogen niet af en toe rusten. 2. De mihing moet in het midden van het dorp worden opgesteld, met den voorkant naar de oeloe. 3 . Alle schatten der feestgevers moeten in deze mihing worden opgesteld. Nadat men rond de mihing heeft gedanst, gaat men binnenshuis het feest voortzetten. Door het opstellen der schatten in de mihing, worden tevens alle sials daarvan weggenomen.

§ 40. Mampendeng Hoeman Oentoeng.

De duur hiervan is drie nachten, en daarna stelt men een offerhuisje, gewijd aan Radja Oentoeng, op. Dit wordt geplaatst op een z.g.n. Boekit toendjoeng, d.i. een kunstmatig opgehoogd stukje grond. Indien dit feest nog niet is afgeloopen, mag geen goed worden ingepakt en mag niets worden vastgebonden.

\$ 41. De palivoorschriten bij deze feesten.

Hebben we thans nagegaan welke bezweringen tot de eerste groep behooren, en in het kort de strekking daarvan leeren kennen, zoo rest ons nu nog, te zien welke verbodsbepalingen men moet in acht nemen, wil de bezwering succes hebben.

I. Voor het maloepoet hadjat is het verboden:

1. Gegeven zaken af te vegen. Immers het feest is een dankbetuiging voor gegeven zaken, en door het afvegen van aangeboden zaken, zou men de Goden doen denken dat de door hen geschonken goederen eenig gebrek hadden (b.v. vuil waren). 
2. Goederen die men reeds gekregen heeft, mag men niet teruggeven of weigeren te ontvangen, want dit zou dezelfde strekking hebben.

3. Het is verboden kleedingstukken los te maken zooals de halsband, tjawet enz.; het ontbinden toch van wat vastgebonden is, heeft de werking van te doen losmaken van wat vast is. (Zie ook bij de geboortegebruiken).

4. Men mag niet op de plaats van het feest twisten.

II. Voor het mampending karamat mag men niet:

1. eten van de pisang die als tangga dienst moet doen,

2. vuur aan vreemdelingen reiken,

3. rijst nemen van het offergestel.

III. Bij het manandang sahoer is het pali :

1. prikkelende spijzen te eten,

2. sterk riekende spijzen te eten,

3. gestorven dieren te eten,

4. spijzen te eten die een nacht hebben overgestaan,

5. wild levende dieren te eten,

6. paddestoelen, schildpadden, hagedissen of krokodillen te eten,

7. te twisten op de plaats van het feest,

8. aangeboden spijzen te weigeren,

IV. Bij het balian harahan is pali:

1. eigen sirih of pinang te eten; men moet dus die van andere personen daartoe nemen,

2 . in een klamboe te slapen,

3. behalve ten dienste van het feest zelve verzorgde dieren te slachten; ook de zaken onder III genoemd zijn voor dit feest pali.

$\mathrm{V}$. Bij het balian hai paloes harahan is het verboden minder dan zeven balians te gebruiken. Tot beëindiging van het feest houdt men een blakoe oentoeng. De verder te houden pali's zijn dezelfde als boven.

VI. Ook het balian hai heeft dezelfde voorschriften, overigens mogen de wachters onder de balai sanggar niet met vreemdelingen, uit andere kampongs af komstig, spreken.

VII. Bij het balian hamihing, mag de feestgever zelve niets aan andere lieden ter hand stellen, doch moet daarvoor de bemiddeling van derden inroepen. 


\section{$\S 42 . \mathrm{Manjaki}$.}

Gaan we thans na welke regelen men voor de tweede groep van godsdienstige feesten in acht heeft te nemen.

Bij het manjaki behoeft men geen gebruik te maken van een palangka. Men moet echter in een gong met drie gantang beras twee sawang boompjes plaatsen, en dien gong op drie hoopjes gras (tambah lampajoeng) zetten. Daarvoor zijn drie poeroenmatten op elkaar gelegd, waarop staan: een oud bord (pinggan salinge), drie of vijf kippen, welke bij het manjaki gebruikt moeten worden, en voorts eenig eten voor de goden. Voor dit feest zijn drie of vijf menschen noodig als teras sawang.

Dit manjaki, de inleiding tot het huwelijk, is den Dajak geleerd door de reeds genoemde Toenggoel Garing en Poetri Boelau. Men zegt, dat daardoor de "gemanjakiden" gereinigd worden van alle sial; trouwens men gebruikt het bij allerlei andere plechtigheden. In Kota Waringin, waar het basangkolan genoemd wordt, is het evenzoo door de eerste menschen aan het menschdom geleerd.

\section{§ 43. Mamboehoel Masak.}

Hiervoor moet een palangka worden opgehangen, drie sawang boompjes moeten in vijf gantang bras geplant worden en vijf pak lampajoeng en drie matten op dezelfde wijze geplaatst worden als in de vorige $\$$ aangegeven.

In de palangka wordt de gevulde piring saling gezet; vijf tot zeven kippen moeten geslacht worden, terwijl even vooveel lieden als teras sawang dienst doen.

\section{\$ 44. Mamboe Sawang Kajoe.}

De palangka moet op palen van bamboe staan. Men moet een sawang kajoe hierbij gebruiken, doch als men deze niet kan krijgen, mag ook de gewone sawang-tak gebruikt worden, maar in dat geval moet men op een plank een sawang kajoe teekenen. Voorts zijn noodig: drie gewone sawang-boompjes in drie gantang beras te planten, drie tampak lampajoeng en een zeven dubbele laag poeroenmatten. Er moeten vijf tot zeven kippen geslacht worden en even veel teras sawang zijn.

De bij al deze feesten gebezigde sawang-boompjes zijn takken van dit struikgewas; ze staan tijdens het feest in een gong met 
rijst, maar worden daarna in den grond geplant bij het huis van den feestgever. In den regel groeien ze zeer snel en goed op: De piring saling wordt natuurlijk ook bij dit feest in de palangka gezet.

Ook dit is een gebruik bij het huwelijk in zwang; de huwelijkscandidaten houden dan het sawang-boompje vast, op een manier die we later gelegenheid zullen hebben te behandelen.

\section{§ 45. Mampandoi.}

Aangaande de teras sawang, palangka enz. zijn de voorschriften als voor het belakoe oentoeng (\$46); er moet echter bij het mampandoi tevens een mihing (offermand) aan den oever der rivier worden opgesteld. Vanaf het huis moet voorts een snoer aan elkaar gebonden klapperbladeren naar het badvlot gemaakt worden, waar het aan de mihing wordt verbonden. Dit is de tatean bawang.

Netten, steenen, de sluiting van het werpnet en dergelijk vischgerij moeten bij den rand van een gong gelegd worden.

Voorts wordt in een tempajan, waarin bloemen zijn, een bepaalde hoeveelheid water geschept. Verder wordt een oude klapper als parapah (dit is de naam van een klein offer, grootere noemt men sahoet of sahoer), er in gedaan. Het kind dat kgemandied» zal worden moet een halsketting van zilveren munten dragen; indien echter de te mandiën persoon reeds eenigen leeftijd heeft bereikt, worden deze munten om zijn armen gebonden. Nadat het mandiën heeft plaats gehad, moet de persoon in kwestie over al de vóór de huistrap neergezette zaken, gebruiksartikelen zoowel als waardevolle goederen, heen springen, en ten slotte even op een geslacht varken gaan staan, welke laatste bezigheid men inampa djahan noemt. Ook wel worden een zevental potten met water gevuld in de hoop dat de Sangiang daar wat danoem Kahiringan bijvoegen zal. Is 's morgens meer water in de potten, dan zijn de Sangijangs goedgunstig geweest. Het water wordt met varkensbloed gemengd, en daarmee wordt het kind besprenkeld. Overigens zijn dan de ceremoniën gelijk.

\section{§ 46. Belakoe Oentoeng.}

De palangka moet staan op stijlen van gele bamboe, die bij de knoopen tot franje is afgeslepen; de uiteinden zijn gespleten en 
in den zoo ontstanen trechter zijn schoteltjes eten geplaatst voor de opgeroepen hoogere wezens.

Vóór de palangka worden opgesteld: drie sawang-boompjes in drie gantang beras, zeven tambah lampajoeng en zeven matten; zeven kippen moeten geslacht worden en tot zeven teras sawang. In de palangka wordt de pinggan saling gezet met het bijbehoorende eten. $\mathrm{Al}$ de zaken in de palangka opgesteld, moeten tevens op de planken van de palangka geschilderd zijn.

\section{§ 47. Mamoengkal Oentoeng.}

Hiervoor moet men een nieuwe palangka maken (deze palangkas n.l. gebruikt men voor elk feest weer opnieuw); ze worden veelal dichtbij de heilige potten aan den zolder gehangen, en daar bewaard. De tiangs worden steeds nieuw gemaakt, en de oude stijlen worden bewaard. In een familiehuis ziet men al deze voorwerpen te zamen gebonden op een der hoofdpalen van het huis staan, voorts zeven tambah lampajoeng, zeven matten, drie sawangs geplant in zeven gantang beras; negen tot elf kippen moeten worden geslacht, en zeven tot negen is het aantal der teras sawang. Voor de palangka moet nog een groote mat gelegd worden, in de palangka de piring saling met bij behoorende spijzen.

\section{$\S 48$. Nasaran Sawang Poeser.}

Dit feest wordt gehouden voor de jong geborene, en is een bezwering voor het afvallen van den navelstreng, met het doel dat het kind in leven moge blijven.

Het te gebruiken materiaal moet zijn als dat bij het belakoe oentoeng. Bij de bereiding van het eten, dat in de palangka gezet wordt, mag geen ijzer aangeraakt worden. We zullen deze bepalingen later bij de geboortegebruiken nog eenige malen tegen komen. Het gebruik van ijzer zou den navel van het kind doen opzwellen. Hij die het kind de vereischte kalong ombindt zal alvorens daartoe over te gaan het voorwerp moeten 'menjaki met het bloed, dat op een bordje in de palangka staat; dan wordt door den persoon, die het feest leidt, een stukje van de sawang afgesneden, waarbij het handje der pas geborene zoogenaamd meehelpt. Het afgesneden stukje wordt naast de sawang gelegd en moet het afgevallen naveltje voor- 
stellen, en het sawang-boompje is het kind, dat gezond en wel dit gebeuren heeft doorleefd.

\section{\$ 49. Blakoe Toentoeng Oentoeng.}

Nagenoeg dezelfde voorwerpen worden gebezigd als in 848 genoemd zijn, met bijvoeging van een klapper, die aan den top der sawang wordt bevestigd, welke sawang een groote lengte moet hebben. Voor de bereiding der rond te dienen ketoepat, moet men zeer jonge pisangbladeren gebruiken, die pas zijn uitgekomen. De rijst voor de maaltijden, zoowel als de ketan, moet men verkrijgen door steeds een gantang vol te scheppen, zoo dat er een kop op staat; deze wordt afgestreken, en deze bewerking herhaalt men, totdat men voldoende heeft voor de spijzen. Het vuur om de spijzen te bereiden moet verkregen worden door het branden van doerian-hout. De te genieten pisang mag niet van den boom gevallen zijn maar moet worden geplukt. Ook hierbij moeten de te slachten kippen gedood worden middels mesjes van bamboe.

\section{§ 50. Blakoe Toentoeng Tahaseng.}

Dit feest wijkt alleen in zooverre af van het sasaran sawang poeser dat men tot het bereiden der eetwaren slechts een vuur van gesprokkeld hout mag bezigen; de stijlen van de palangka moeten vervaardigd zijn van kadjoendjoeng hout, ze moeten alle van bamboe franje voorzien zijn, en naast elk moet een rawajang staan, d. i. een lans om visch mee te steken. De ketan moet in een klappernoot bereid worden. Ook thans mag men niet met ijzer aan het te bereide raken; rondom de palangka worden als extra wanden vier slendangs gehangen.

Dit feest wordt zeer veel gehouden na de geboorte, en heeft dan de beteekenis om de levensstof, die eventueel in de nageboorte is achter gebleven, tot het kind te doen overgaan.

\section{\$51. Mamboeng Karoehai.}

De palangka moet op stijlen van gele bamboe staan; de teras sawang bestaat uit zeven tot veertien menschen; den avond van te voren mag de eigenaar der karoehai niet slapen. Gedurende het feest moet hij het toovermiddel vasthouden; als hij het neerlegt, moet dit op een gong gelegd worden, waarin de sawang geplaatst is. Dien avond wordt de karoehai 
ook weer omgebonden, om de pols of het middel van den eigenaar. Verder vervaardigt men een hampatoeng als palekang karoehai, d. i. een kleine bus waarop een menschenbeeld, waarin de karoehai bewaard wordt na het feest.

\section{$\S 52$. Blakoe Oentoeng Parei.}

Palangka op stijlen van groene bamboe, waarbij minstens vijf kippen moeten gebezigd worden. Men plaatst de rijst (padi) in een bakoel, die men naast den gong met sawang zet, welke bakoel met kralen moet versierd zijn. Men moet alvorens dit feest te kunnen vieren een deel van zijn veld beplant hebben, eerst daarna kan men deze bezwering houden. De padi in de bakoel mag niet gebruikt worden voor eten, het zij voor mensch of dier, maar moet geplant worden op het bouwveld des feestgevers. Dit planten kan eerst plaats hebben na een pali-periode van drie dagen, na afloop waarvan een kip geslacht wordt.

\section{§53. De heilige potten.}

Alvorens de beide laatste feesten te behandelen zullen we eerst dienen kennis te maken met de heilige potten der Dajaks. Wij bedoelen de voorwerpen, die men aan bovennatuurlijke makers toeschrijft, en welker gana, meestal hambaroe geheeten, groote hulp aan den eigenaar, en ieder ander die haar hulp inroept, kan brengen. Ze stellen met de gongs de schatten voor die de Dajak bezit, naar welker aantal zijn rijkdom wordt afgemeten. De aankoop van een exemplaar is een gebeurtenis in zijn leven, en geschiedt veelal niet zonder hulp zijner verwanten. We zullen dan allereerst den oorsprong dezer vaten nagaan. Hardeland geeft i. v. Radja een verhaal dat een weinig van het door mij vernomene afwijkt: De vorst van Modjopait, Radja Pait genaamd, had een beeldschoone dochter, Poetri Koedoeng geheeten, aangezien ze lijdende was aan een soort lepra, waardoor haar vingers en teenen waren afgevallen. $Z_{\mathrm{ij}}$ had den huwbaren leeftijd bereikt en er werd vastgesteld, dat hij, die haar zou genezen, de prinses zou trouwen en de opvolger des konings zou worden. Sangoemang zulks vernemende, ging met zijn vriend Papaloi op weg, en wist de genezing door de hem eigen wijsheid tot stand te brengen. Het huwelijk had met groote plechtigheid plaats, en het duurde niet lang of de prinses was in blijde verwachting. Sangoemang begrijpende, dat hij niet 
steeds op aarde zou kunnen blijven, was bedacht op de toekomst van zijn kind en besloot dit, zoo hij de aarde verliet, in het genot te stellen van groote rijkdommen. Sangoemang zei deswege zijn vrouw aan, dat hij 's nachts in een ander vertrek zou verblijven, maar dat zij daar volstrekt niet binnen mocht komen. Daar bereidde hij met Papaloi de kostbare vaten, die hij maakte van aarde gemengd met goud en een weinig maanaarde, die Sangoemang in vroeger tijd op listige wijze aan Kadjangga ontfutseld had, die het op zijn beurt op onrechtmatige wijze van Mahatara ${ }^{1}$ ) had weten te verkrijgen, toen deze de maan schiep. Hoe het zij, vrouwen zijn nu eenmaal nieuwsgierig, en zoo ging op zekeren nacht de prinses op onderzoek uit. Ze opende de deur van het geheime vertrek en zag daar haar man en diens vriend in hun ware Sangiang-gestalte, dewelke uiterst groot is. Te zelfder tijd verdwenen beiden; Sangoemang echter zei zijn vrouw, dat zij aan haar zoon moest zeggen, dat als hij oud genoeg was, hij de soempitan en mandau zijns vader moest aangorden, en dat hij dan zou komen om hem rijk te maken. De zoon groeide zeer voorspoedig op, en toen hij aan de eischen voldaan had, wees Sangoemang zijn zoon zeven bergen aan, die vol stonden met heilige potten. Dit alles werd hem gegeven, maar eerst moest hij daar omheen een pagar bouwen, tijdens welk werk niet gesproken, gegeten en gedronken mocht worden. Zoo geschiedde, maar toen de schutting bijna gereed was, maakten eenige werklieden krakeel, waarop de potten opsprongen en vluchtten, meestal in de gedaante van herten. Snel sloot men nu de schuttingen, het resteerende was genoeg om den zoon rijk te maken. Die potten zijn de heilige vaten der Dajaks geworden; de meest kostbare, zooals we later zullen zien, dragen de teekenen door Sangoemang zelf gemaakt te zijn, verreweg de meeste echter zijn door Papaloi gemaakt.

De weggeloopen potten komt men af en toe nog tegen. Zoo toonde men mij aan de Kahajan een kostbare blanga, aan welks buik een gat was als een speerwonde, dat met een zilveren prop was gesloten. Deze pot was in overoude tijden gevangen in den vorm van een hert, en toen men het dier doodde veranderde

1) Anderen zijn van oordeel dat de potten vervaardigd zijn van de zeer vruchtbare aarde uit Sangiang-land, de zgn. petak kesamboejan, gemengd met danoem Kahiringan en Karoehai hout. 
het in een blanga. Andere weer vindt men in den grond, en dit is een gunstig teeken; immers de ziel van den pot is den vinder tegemoet gekomen, wat veel goeds belooft voor de toekomst. (Manoeah noemt men dit ontmoeten).

Daar de potten kostbaar in hooge mate zijn, er zijn exemplaren, die tot $f 6000$. - waard zijn in het oog der Dajaks, is het te begrijpen dat de aankoop een kwestie is die niet alleen de individu, maar zijn gansche familie raakt; een ieder draagt dus bij de aanschaffing naar beste krachten bij. We zullen thans nagaan wat men bij den aankoop in acht heeft te nemen. Indien men een blanga koopt aan de oeloe, dan maakt men een rakit, waarop dit heilig vaatwerk wordt geplaatst. Is men de kampong tot op korten afstand genaderd, dan heeft men in een tadjahan of pahewan eenigen tijd te verblijven, en minstens een nacht te overnachten; ook moet dan een kip geslacht worden.

Er wordt van daaruit kennis gegeven aan de kampong, opdat men daar een en ander in orde kan brengen voor het komende feest. Vervolgens wordt de pot naar de kampong gebracht; dan wordt met sawang-bladeren, de persoon, die den pot brengt, 'gemanjakied, terwijl hij bestrooid wordt met de aangezette korst uit een rijstpot. Zoowel de brenger van de blanga, als de blanga zelve, mogen niet door de deur in huis komen. Daartoe wordt een gat in het dak gemaakt, waardoor beiden naar binnen worden gelaten. Is dit gebeurd, dan wordt ten spoedigste dit gat weer dicht gemaakt. Een en ander zou tot strekking hebben, dat de hambaroean van den heiligen pot niet zal wegloopen om zijn oude woning weer op te zoeken. Het is immers een gewoonte der zielen, om bij hun reizen steeds denzelfden weg te volgen, en waar hem nu de weg, dien hij gekomen is, is afgesloten, zal hij in de woning des toekomstigen eigenaars moeten verblijven.

Er wordt nu eene kleine balei gebouwd waarin de blanga geplaatst wordt, en die den naam draagt van djarah blanga. Indien zich in het huis reeds andere heilige vaten bevinden, zoo moeten deze worden aangebracht en rondom de djarah opgesteld. Voor de blanga's nu wordt een antjak opgehangen van elliptischen vorm, dien men cantjak rohan» noemt. Vervolgens worden drie tot zeven kippen en een varken geslacht; de opstelling der blanga's, zooals boven vermeld, blijft zeven dagen dezelfde, in welken tijd men elken dag nieuwe kippen Dl. 80. 
slacht om in de antjak spijs voor de hambaroean te kunnen leggen. Den laatsten avond wordt een varken geslacht om het "manjaki blanga» te bewerkstelligen, en wordt een maaltijd voor genoodigden in gereedheid gebracht.

Een ieder, die de blanga persoonlijk wenscht te bestrijken met het bloed van het offerdier, moet daartoe een betaling doen aan den feestgever, de zgn. “tewoes koeloek» (tewoes= tehoes $=$ afkoop, koeloek $=$ kop), zijnde dit dan een afkoop voor den kop van het offerdier; men trekt immers de voordeelen van het manjaki, zonder de onkosten van een offerdier te maken.

Op den dag, waarop het slachten van het offerdier plaats heeft, wordt een zevental hampatongs vervaardigd, die men in dit geval denzelfden naam geeft als die, welke opgesteld worden ter eere van een voorteeken der antang, n.l. tadjahan. Deze tadjahan blanga wordt voor het huis - rechts als men binnen gaat - geplaatst. Men ziet ze veelvuldig in de bovenstreken, meestal worden voor de poppen de sawangs geplant. Bij voorkomende gelegenheden hangt men ook in den tadjahan een antjak op, of offert zijn gaven in een daartoe in het sawangboschje opgerichte balei. Allen, die de blanga na betaling, met bloed bestrijken, mogen daaraan een belofte verbinden bij vervulling van een wensch; ze hebben dan echter een kleine hoeveelheid eten in de antjak te plaatsen. Dit "manjaki blanga , noemt men Taharang Blanga.

Gaat men vanuit het dorp echter de blanga tegemoet, daarbij vergezeld van de balians, dan is het niet noodig dat men, alvorens de kampong binnen te gaan, aan een heilig boschje overnacht, doch mag direct de kampong betreden.

Komt een koopman in heilige potten, zonder zeker te zijn van verkoop, in een kampong aan, om zijn waar te slijten, dan is het niet noodig, dat - alvorens het huis betreden wordt de kostbare zaak door het dak naar binnen wordt gebracht. Dit is, in verband met de verklaring boven gegeven, duidelijk.

Men gaat nu over tot de vaststelling van den prijs en van de goederen waarin betaald zal worden; is dit geschied dan worden al de betrokken goederen klaar gezet en de verkooper laat de blanga opnemen, terwijl hij kennis geeft, dat voortaan dit heilig vaatwerk van den kooper is. Deze neemt den pot aan en geeft kennis aan de aanwezigen, dat hij daarvan eigenaar 
is geworden. Bij dit ceremonieel moeten kooper en verkooper netjes tegenover elkaar zitten.

Thans worden een varken en eenige kippen geslacht door den kooper, die daarmee verkooper, blanga en te betalen goederen "manjakiet»; daar tegenover staat, dat de verkooper den kooper een tegoeh ( $=$ kwitantie, meestal een ijzerhouten popje) geeft.

\section{\$54. Mandjoeng Ganan Blanga.}

Het boven reeds vermelde ceremonieel van mandjoeng ganan blanga gaat steeds gepaard met het reeds behandelde mamboeng karoehai. Voor dit feest is het niet noodzakelijk dat er een palangka is. De toerusting tot dit feest is als volgt.

Er moeten zijn zeven balians, een sawang-tak, die zich van boven in drie zijtakken splitst, vijftien kippen, rijst om de sawang te planten, zeven gantang, een oud bord in de antjah rohan voor de blanga, veertien personen teras sawang, van wie elk een kraal moet krijgen. De blanga moet aan zijn ooren een ketting kralen hebben. Ten slotte moet 's morgens van den dag van het feest een varken geslacht worden ter waarde van zeven keping ( $f$ 14.-.)

Voor het tahareng is, behalve het in de vorige paragraaf reeds genoemde, nog noodig een palangka te vervaardigen. De blanga moet steeds, òf in een gong òf in een sangkoe (koperen kom) staan gevuld met rijst, en rondom de blanga moeten gouden voorwerpen gelegd worden.

Indien men de tadjahan blanga opstelt, wordt boven de opening der blanga een antjak gehangen gevuld met rijst en kip. Deze antjak moet precies de grootte hebben van de halsopening van den heiligen pot.

Is de pot welken men gekocht heeft een halamaung, dan verandert het ceremonieel. Bij het aanbrengen uit een ander dorp toch heeft men geen gebruik te maken van een vlot, evenmin is het noodig een aantal nachten bij een tadjahan te overnachten, alvorens de vestiging te betreden; het tahareng mag niet gehouden worden, men behoeft geen plaats op te richten, waarin de pot gezet wordt, men behoeft hem niet door het dak binnen te laten, en evenmin is het noodig dat men de groote antjak boven de monding der halamaung hangt.

$\mathrm{Na}$ het mandjoeng gana halamaung wordt een varken geslacht, 
waarbij meestal als vervolg het mamboeng karoehai wordt verricht. Op een dusdanige wijze gevierd in bezit geraken van een heilig vaatwerk zal den mensch behoeden voor moeiten, ziekte en zorgen (dia pangapaha pahabanbasial).

\section{§55. Soorten heilig vatwerk.}

Hebben we thans gezien welke ceremoniën gevolgd worden bij den aankoop en het met bloed bestrijken der heilige potten, nu zullen we eenige kenmerken der verschillende soorten opgeven; ik zal mij daarbij slechts bezig houden met die vaten, welke ik persoonlijk heb gezien. In de eerste plaats moet er dan de aandacht op gevestigd worden dat deze potten, zooals begrijpelijk is, veelvuldig worden vervalscht. De Dajak is echter niet zoo gemakkelijk op dat gebied te bedriegen, hoewel het soms toch voorkomt. Meerdere malen heb ik echter een valschen naast een echten laten zetten, en hoewel ik de echten toch tientallen van malen grondig bezien heb, kon ik geen verschil opmerken; toch zei elke Dajak van eenige zakenkennis mij zonder bedenken en zonder missen, welke pot de valsche was. Des gevraagd beweerden zij dan steeds zulks aan den glans van het vernis te zien.

Is een blanga gebroken, dan wordt hij weer netjes aaneen geplakt, maar de waarde is verminderd; is hij in al te veel stukken gebroken, dan heeft dat herstellen niet meer plaats. Maar de stukken op zich zelf zijn dan nog zeer prijzig, immers zij alle hebben een deel der gana van het geheel in zich, en kunnen - zij het dan ook niet in de mate van den heelen pot den eigenaar geluk aanbrengen, en hem bewaren voor sial.

Thans iets over de verschillende soorten.

Halamaung Rentian. Alle heilige vaten hebben een hoogte van ongeveer 60 c.M. en een grootste breedte van \pm 40 c.M.; op $2 / 3$ der hoogte is deze grootste omvang, de voet en de hals hebben een doorsnede van \pm 20 c.M. Op het lichaam, even boven den buik en ten deele nog daaròp, zijn naga's aangebracht, die verschillende standen, ten opzichte van elkaar en van de ooren van den pot, innemen. Deze ooren zijn zes in getal, al dan niet eindigende in een kop, en met een verschillend aantal ribben versierd. De halamaung rentian heeft in leeuwenkoppen (patong) uitloopende ooren, gesierd met drie ribben (roengkoe), welke ribben van elkaar gescheiden zijn door twee deuken (soerak). De opening heet baoeng djaoet (baoen = gezicht, djaoet, djawet 
tadjau $=$ oude pot). We treffen als versiering van het lichaam twee naga's aan, die met de koppen naar elkaar toegekeerd zijn (hatoenggep). De staarten, ikoe, zijn gegolfd en raken elkaar bijna. De muilen zijn opengesperd en zoowel in boven- als onderkaak bevindt zich een slagtand (singgal), de tong (djo'a) is uitgestoken en achter in den mond, tegen het kaakgewricht aan, bevindt zich een ronde bal of vrucht, de z.g.n. boeah loehoek. Vóór de oogen, op den neus is een bult, die men djoenggoel noemt en op den kop staat een gespleten hoorn (tondo); twee oogen zijn aangebracht, alsmede een recht overeind staande kuif (bau). Aan de pooten (sapak) zijn vier teenen, drie naar voren gericht (sioe), en één, als een spoor, naar achteren (tadji).

De schubben op het drakenlichaam zijn als strepen aangegeven (toendingdjikot), de hals (oejat) van het dier is licht gebogen, de rugvin (tain raba) loopt tot achteraan door.

Het onderste $\frac{1}{3}$ gedeelte van den pot is niet vernist en heet de poera, het verniste noemt men sapoe; de kleur is bruin geel. De bodem van den pot (ka'ang) is doorboord als een bloempot; het gat heet toeboes. Als waarde wordt genoemd $f 1500$.-

Men heeft bij al deze potten, behalve bij de basirs, twee geslachten nl. hatoea (man) en bawie (vrouw). De vrouwelijke dezer soort onderscheiden zich door twee kleine draken in plaats van de beide bovengenoemde. De waarde der vrouwelijke potten is beduidend lager dan die der mannelijke; zoo is de besproken soort in het vrouwelijke slechts $f$ 400. - waard.

Halamaung Hatoenggep. Onder de naga's zijn golven (pitih) aangebracht. De schubben der naar elkaar toegekeerde naga's zijn aangebracht als rijen onder elkaar geplaatste streepjes,

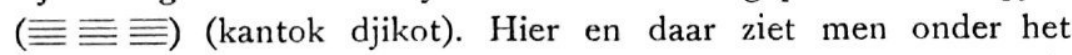
vernis groote, hard gele vlekken (enjah manoek $=$ kippenvet), overigens als boven. Waarde $f$ 1400.-

Halamaung Sahai. Deze pot vertoont geen naga's, maar slechts krullijnen en bloemmotieven. De zes ooren staan dwars, en niet als bij andere potten in de lengte. Om de ooren zijn krullen aangebracht (oehat marau). De bloemmotieven worden boeah mardu genoemd. De ooren hebben drie ribben ( $\pm f 1600$.- -

Halamaung Sengarang. ' 2 naga's hatoenggep, met 4 nagels aan de teenen. De schubben, toendang djalihep, zijn in rijen achter elkaar geplaatst op deze wijze $\equiv \equiv \equiv \equiv$. Om de ooren loopen over elkaar vallende, vijfdubbele krullen (oerat tingang). Onder de 
naga's is een vijfdubbele golflijn, waarvan de golf naar beneden is gericht; de puntvormige samenkomst der golven is naar boven gericht (krawang hakoen).

Bawin Halamaung, met drie kleine naga's, die alle achter elkaar gaan; teekening uiterst onduidelijk, drie teenen aan den klauw (vrouwelijke pot).

Roemoes Lalang Karing, ooren met vier zeer smalle ribben; de dalen zijn groot, eindigend in hampatoeng.

Basir Ratian, twee naga sahajap, in de bovenkaak tanden; drie teenen; drie breede oorribben; geen verdere versiering.

Andere soorten halamaungs zijn de Halamaung Sahaiak ( $f 1000 .-$ ), Halamaung Brahan ( $f 2500 .-)$.

De zeer kostbare blanga's, n.l. die, welke de teekenen dragen door Sangoemang zelf gemaakt te zijn, dragen alle een eigen naam. Ik zal er slechts eenige behandelen.

De Blanga Daroem Bawan. De hals versierd met een en relief gewerkten band (bohot), een teeken van Sangoemang's werkzaamheid, twee kleine naga's die met de koppen van elkaar afgewend staan (sahajap), zes ooren met vijf ribben (roengkoei) daarop en vier soerak, schubben over de geheele breedte van het naga-lijf als strepen aangegeven $(/ / \mid)$, drie teenen aan de pooten, om de ooren krullen (oerat tingang); de ooren loopen niet in patongs uit, maar zijn als het ware met den vinger op den pot gedrukt. Het zoo ontstane platte vlakje is evenzeer een teeken van Sangoemang's eigen arbeid; men noemt dit pitik Sangoemang. Deze pot was maar tot op de helft van glazuur voorzien en er was bloedgeld mede betaald, zooals kenbaar was aan het ontbreken van een oor, dat, ingeval van Sahiringbetaling, van den pot wordt afgeslagen. Waarde $f 5000$.-

De Blanga Randang, zes ooren uitloopende in patongs, vier roengkoei's en drie soerak-bogen onder de ooren (garing bawai), naga's in elkaars verlengde (sahajap), vier teenen, op de rugvin vijf punten (toengkoen Sangoemang), evenzeer een teeken van Sangoemang's kunst. De bovenkaak is voorzien van vele tanden, de onderkaak is slechts met één tand gesierd. Schubben aangegeven als aan elkaar sluitende gaatjes (kawan batoe), achter de rugvin een verhooging (toetoek kajoe) en vóór de rugvin een verhooging poeloet genoemd. Onder de naga is de pot versierd met gegolfde lijnen (koendjat), de toppen en dalen dezer golven zijn spits, terwijl de pitik's rond zijn. Waarde wordt geschat op $f$ 3600.-. 
Blanga Nanang Moesoe, zes ooren met vijf ribben (roengkoei) en vier scheidingen (soerak) daartusschen, die minder diep zijn dan bij de vroeger genoemde. De ooren loopen niet uit in hampatongs, maar zijn als het ware scherp afgebroken. De beide naga's staan in den stand sahajap. De kop is gesierd met twee tandoeks zonder kuif, geen tatak kajoe is aanwezig. De rugvin van den eenen naga draagt vijf toengkoe Sangoemang, van den anderen naga zes. De bovenkaak (djoenggoel) is lang, naar boven omgebogen, de onderkaak (hidjang) kort, beide tandeloos, zonder vrucht in den bek, aan de teenen drie nagels. Onder de naga's een golflijn bestaande uit drie dicht op één geteekende lijnen (tihis). De schubben zijn als een lijn van vrij diepe en breede, achter elkaar liggende strepen aangegeven (taling lawai). Waarde $f 3000$. - . Het exemplaar dat ik zag bestond uit een kleine honderd aan elkaar geplakte stukjes; de waarde was daardoor tot $\pm f 2500$. - gedaald.

Blanga Hewan, twee naga sahajap, schubben alleen tisik geheeten, twee horens, sterk omgebogen bovenlip, drie teenen, onder de pot-ooren golflijnen (salipan), onder den naga: letok soeli. De eerstgenoemde golflijnen bestaan uit drie golflijnen onder elkaar, die schuin gerichte golven vormen. De laatste is een dubbele golflijn elk uit drie lijnen bestaande. De ooren loopen in drie hoeken uit.

Blanga Alas, twee naga sahajap, de eene met vijf toengkoen Sangoemang op de rugvin, de andere met zes vóór de rugvin panggit poeloet (een vierhoekige bult). Waarde $\pm f$ 4000.-.

Blanga Nawai, twee naga sahajap, vier nagels, staart zóó gebogen dat ze onder de ooren van de blanga doorloopt. Om den hals van den pot een band uit twee donkere lijnen (bohot), pot-ooren met vier ribben, onder de naga's vier rijen van dubbele, op eenige plaatsen drie-dubbele golflijnen (lamoendjan), die hier en daar onderbroken zijn; vóór de rugvin pangat poeloet, boven de naga's om de pot-ooren krullen (oelat tinggang), tanden in de onderkaak ( $f$ 4000.- -).

We hebben boven reeds gezien, dat het gebruik is, de heilige vaten te versieren. Men ziet ze dan ook in het huis staan, meestal met door de ooren een rotanband (intoeng); aan de ooren hangen snoeren kralen (kaloeng manik) en tingang veeren. In vele gevallen is de opening afgedekt door een gong, die men in dat geval langgoei (hoed) noemt, terwijl de heele 
pot ook meestal in een rotan vlechtwerk is geborgen, zooals in Europa voor gemberpotten wel gebruikelijk is. Minstens eens per jaar moet de pot "gemanjakied" worden met varkensbloed, en af en toe legt men eenig eten voor hem neer, in een antjak. Laat men den pot zien, dan wordt met klapperolie de stof, die meestal in een dikke laag over den pot ligt, verwijderd. Het vertellen der geschiedenis van bepaalde potten is pali, welk verbod kan worden afgekocht door het slachten van een kip. Dit is steeds de voorbereiding om de geschiedenis der blanga in kwestie te kunnen vernemen; doet men dit niet, dan verneemt men een gefantaseerd verhaal.

Ter illustratie dat de waarde van een blanga door breken niet geheel verloren gaat mogen de volgende vergoedingsbepalingen gelden. Wie iemands blanga stuk makt, moet den eigenaar een echte halamaung betalen, benevens een varken voor het taharang. Wie iemands halamaung vernielt betaalt den gedupeerden eigenaar daarvan, een pot van de soort basir ter waarde van vijf djipen ( $f 200 .-)$. Is echter de in ruil gegeven basir ook stuk geweest en dus gelijmd, dan moet men bovendien drie djipen bijpassen.

\$ 56. Nadere gegevens betreffende de boven beschreven godsdienstige plechtigheden.

De bezweringen uit te spreken bij het tantoelak, maloepoet hadjat, mempendang keramat en menambang sahoer, zijn den menschen geleerd door Maharadja Boenoe, en zijn veelal doorspekt met gebeurtenissen uit diens leven. De andere zijn inzettingen welke van Maharadja Sangen afkomstig zijn.

De verbodsbepalingen die in $\S 41$ zijn behandeld, heeft men in acht te nemen op straffe van het lasampilen, d. i.: het getroffen worden door sampilen, d. w. z. bewusteloos worden; de ziel zal ontwijken, indien men zich niet in acht neemt. Heeft men echter toch een dusdanige fout begaan, dan zal men de kwade invloeden kunnen afwenden. Men ziet dan - ook als men zich niet bewust is gezondigd te hebben - na zulk een feest den feestgever een offer brengen aan die sampilen, meestal bestaande in kip en rijst, maar soms ook uit een varken. Zoodra dit alles is afgeloopen, worden de palangka en antjak afgenomen en met bloed bestreken, en daardoor worden als het ware de medegewerkt hebbende geesten bedankt. 
Vervolgens moet hij zich naar de andere lieden der kampong begeven voor het z. g. n. maniwah pali (het zich reinigen van het pali); (terai pali $=$ ophouden van het pali). Daartoe moet dan de persoon, in wiens huis de voormalige feestgever komt, een kip slachten, met het bloed waarvan hij wordt ingesmeerd, terwijl hem een kralen armband wordt omgebonden en hij met rijst wordt bestrooid. Is echter de vrouw des feestgevers zwanger, dan zal men tot het manjaki slechts het bloed uit den kam van een levende kip mogen nemen. Later zullen we zien, wat de reden daarvan is.

We hebben thans redelijk uitvoerig gezien, hoe de bezweringen plaats hebben, en zullen in het verloop dezer verhandeling nog meerdere malen bij de speciale gebruiken nadere aanvullingen kunnen geven van het vermelde.

\section{$\S 57$. De voorteekens.}

Waar een zoo groot aantal belagers van het menschdom bestaat, is het begrijpelijk, dat er ook middelen bestaan, die ons aanwijzingen kunnen geven over het verloop van voorgenomen handelingen, en dat er talrijke middelen zijn waarmee men zich kan wapenen tegen de funeste invloeden, die op ons werken, of die ons de hulp verschaffen van bepaalde hoogere wezens.

Allereerst zullen we dan overgaan tot de voorteekens.

Deze zijn van tweeërlei aard:

$a$. die gegeven worden door andere levende wezens.

b. die toevallige gebeurtenissen zijn. Deze laatste echter zijn minder voorteekenen; de persoon in kwestie is eigenlijk daardoor in een toestand van sial gekomen, die hem dus in een uiterst gevaarlijke positie doet verkeeren. Onder dezen noem ik slechts eenigen uit velen. B.v. men zal op reis gaan en struikelt over den deurdrempel, rolt van de huistrap enz., of men niest eenige keeren achter elkaar bij het vertrekken. Het is een teeken van sial, men zal de reis niet aanvangen, maar deze een dag of langer uitstellen.

Onder de eerste groep staan in den eersten rang de voorteekens door vogels, slangen en andere dieren gegeven; men pleegt daartoe in staat zijnde levende wezens samen te vatten onder den verzamelnaam ,,dahiang”.

Elke familie heeft zoo haar eigen speciale soorten, die voor haar van belang zijn, en die in gewone gevallen niet door 
andere geraadpleegd worden, tenzij dat de eigen dahiang's zich gedurende korter of langer tijd ernstig misdragen hebben door verkeerde voorspellingen te doen. In welk verband deze dieren tot de familie staan, is den menschen niet recht duidelijk, maar een feit is dat men de familie-dahiang niet pleegt te dooden. Zoo lezen we zelfs in een dagboek van den gezaghebber van Zuid-Borneo over het jaar 1849: "zoo zei mij b.v. een hoofd van de Aroet, dat niemand zijner familie hertenbeesten vleesch mocht eten, dewijl reeds van de tijden zijner voorouders diegene zijner familie, die genoemd vleesch hadden gegeten, na hunnen dood in hertenbeesten veranderd waren.,

Ik hoorde persoonlijk bovenstaand verhaal niet, maar wel verklaarde men mij, dat de dahiangs zeer na aan het menschengeslacht verwant zijn en de plicht hebben, al dan niet daarnaar gevraagd, waarschuwingen te geven betreffende komende gebeurtenissen.

Het zou dus niet onmogelijk zijn dat we hier nog met een overblijfsel van Totemisme te doen hebben.

De slangen zullen we later ook nog een bijzondere functie zien vervullen bij zwangerschap.

Naast de familie-dahiangs ziet men eenige vogels, die algemeen erkend worden als begiftigd met de gave der voorspelling. Dat zijn dan in de eerste plaats de twee sterk in Borneo opvallende vogels n.l. de neushoornvogel (tingang) en de groote roode valk of kiekendief (antang). De eerste is, zooals we boven reeds zagen, een hulp der Sangiangs, wiens schip hij trekt en wier berichten hij rechtstreeks den menschen kenbaar maakt. De laatste, die zeer veel voorkomt, werkt slechts op verzoek. Het teeken door hem gegeven noemt men tadjah.

Wil iemand een zeer belangrijke onderneming beginnen dan maakt hij zich zeven houten poppen die hij op een rij in het bosch zet, op een schoon gekapte plaats. Zooals de Europeesche knoopenteller, elke knoop van zijn jas aanrakende zegt, als antwoord op de door hem gestelde vraag: ja, neen, ja, neen enz. zoo wijst de Dajak de poppen aan, zich voorhoudende dat als de antang over deze vliegt zijn slagen zeker is, en als het over de volgende mislukt, hij bij de daarop volgende zal slagen, enz. Thans wordt rijst gestrooid en de antang opgeroepen; in den regel - men kiest een plaats uit waar de dieren zich vaak vertoonen - zal al spoedig al draaiend en „menariënd" 
een antang verschijnen. Nu moet er op gelet worden of hij over de hampatongs vliegt; gebeurt dit, dan is de pop die ,overvlogen" wordt de brenger der boodschap. Vliegt de vogel over alle of meerdere, dan is dit geen teeken, evenmin als hij langs de zeven poppen vliegt. Komt de vogel van het Oosten en keert hij daarheen terug, na een goede pop te hebben aangewezen, dan is dat een uiterst goed teeken. Komt hij echter van het Westen en begeeft hij zich daar ook weer heen, dan heeft een goede aanwijzing geen zin, en moet men na drie dagen een en ander herhalen.

De plaats nu waar men de poppen heeft opgesteld, is de reeds meermalen genoemde tadjahan; het boschje waarin de opstelling heeft plaats gehad is pali en bij verbreken van dit pali zal men een varken moeten slachten. Na tiwah-feesten en andere groote gebeurlijkheden in de Dajaksche maatschappij pleegt men naar zulke tadjahan te gaan. Langs Boven Katingan, Kalang Mantaja, Samba, Brawi enz. ziet men talrijke zulke boschjes, hetzij alweer volgegroeid, hetzij pas opgeknapt, na een gehouden feest.

Voorts let men erop of deze vogels zonder gevraagd te zijn uw weg kruisen van links naar rechts of van rechts naar links, dan wel of ze vlak boven uw hoofd hun statigen dans uitvoeren. De leer der omina is uiterst moeilijk, en het is mij dan ook niet mogen gelukken met zekerheid vast te stellen wat gunstig is en wat niet. Naast deze vogels zijn verschillende uilsoorten van belang; ziet men het kleine roode uiltje ten Oosten van het huis, dan is dat goed, ziet men hem ten Westen, dan slecht. Passeert u zoo iets op uw bouwveld, dan moet gij het verlaten, want succes met het gewas is dan uitgesloten. Gaat zoo'n uiltje echter op het dak van het huis zitten, zoo zou langer verblijf in dat huis den dood van een der inwoners veroorzaken; men pleegt dan ook zulk een woning te verlaten.

Bepaalde vogels mogen niet binnenshuis komen; dit is een teeken van sial. Men moet offers brengen zoowel aan den vogel, als aan de sambalik (zie $\$ 33$ sub. 5.), die wellicht weer in hun grond zijn teruggekeerd.

Het geschreeuw van de vogels heeft evenzeer zijn zin; zoowel het hooren links en rechts, als het z.gn. "lachen» en "huilen» van speciale vogels heeft beteekenis. Is men vertrouwd met 
dezen tak van wetenschap, dan zal men daar uit kunnen vernemen of geluk of tegenspoed te wachten is. Vooral bij het bestellen van het land zullen we kennis maken met talrijke dieren van dien aard; we zullen dan ook ten aanzien dezer dieren bepaalde voorschriften zien ontstaan.

Behalve deze voorteekens, heeft men ook nog die welke men in den droom ontvangt. We zagen reeds hoe die droomen niet minder zijn dan voorvallen door de ziel beleefd op hare omzwervingen op aarde, en het is daarom ook begrijpelijk, dat men het zoo in den slaap beleefde, maar niet als iets toevalligs beschouwt, maar als iets, dat wel degelijk op de realiteit betrekking heeft. Men heeft zoo ontmoetingen, die ons waarschuwen, b.v. tegen het bewerken van een veld dat men op het oog heeft, enz.

Krijgt men nu op reis een dezer vele voorteekenen, dan zal men, ingeval dit teeken gunstig is, niet nalaten op de plaats, waar ons dit goede omen is geworden, een offer op te stellen, voor diegene, die ons dit teeken heeft doen toekomen. Deze gave bestaat uit wat rijst en kip, of uit eenige andere voorradige goederen, die het hoogere wezen aangenaam kunnen zijn.

Is het teeken slecht, dan heeft men daar ter plaatse aan land te gaan, en een pali-periode van drie dagen door te maken; ook daarbij heeft men natuurlijk de noodige offers te brengen.

Door dezen maatregel tracht men het voorteeken krachteloos te maken. In streken waar reeds eenigermate de beschaving is binnengedrongen, en waar men de kwestie van een verlies van drie dagen reeds als iets min of meer ernstigs gaat beschouwen, ziet men dat de pali-periode wordt vervangen door driemaal snel ronddraaien, waardoor evenzoo geacht wordt de sialinvloed afgewend te zijn. Op de andere plaatsen weer ziet men toevallig de kwade teekenen niet, en worden de goede als welkome teekenen begroet.

Heeft men nu in een bordje zijn offer opgesteld en komt later een ander persoon, die dit offerplaatsje vernielt, dan begaat deze daardoor een strafbaar feit. Immers de afgewende sial-toestand zal daardoor wederom over den offeraar komen. De daarvoor bedreigde boete beloopt een tot twee djipen, benevens een varkentje ter waarde van drie keping en een agaatkraal (in dit geval angkit genoemd.) De boete noemt men als 
het feit het voorteeken der antang raakt: karak antang doehie; het opgerichte offer draagt slechts den naam pinggan sahoer. Het is duidelijk, dat de bij te voegen agaatkraal en het varken moeten dienen om een tantoelak te houden, ter afwering van den door de handeling opgeroepen sial-toestand.

Een andere belangrijke voorteekenvogel is de boeroeng pantis (en de vogel papan); roept hij eenmaal of meermalen in de nabijheid van een woonhuis, dan is dit een slecht teeken, doch geschiedt dit meerdere malen verwijderd van eenige woning, dan is het teeken gunstig. Tot afwending van den slechten invloed of ter bestendiging der goede voorteekens strooit men rijst. Een hoen wordt bereid en eenigen tijd buiten gezet; met het bloed daarvan besmeert men zich, waarna de kip gegeten wordt.

$\S 58$. Voorbehoedmiddelen.

Zooals we reeds zagen kan men zich ook nog met andere middelen, dan de bovengenoemde wapenen. Men kan zich tegen aanvallen van kwade elementen hoeden door bezweringsvoorwerpen, of men kan zich door zulke middelen den steun van geesten verschaffen.

Een machtige steun in zoo'n aangelegenheid heeft, zooals we in $\$ 55$ reeds lieten uitkomen, de bezitter van een heiligen pot in de ziel van dit voorwerp. Wij zouden b.v. ter zake nog kunnen mededeelen dat deze potten bij naderend geluk geluid kunnen voortbrengen, terwijl een komend onheil het vaatwerk van angst doet zweeten.

Meer algemeene middelen, die tevens meer onder ieders bereik zijn, zijn de z.g.n. karoehai's, die we ook reeds enkele malen noemden.

Men verkrijgt ze op verschillende manieren, b.v. men koopt ze van de Maleiers, in welk geval ze bestaan uit strookjes papier, met daarop voorkomende Qoeranteksten, of ook wel met iets wat daarvoor moet doorgaan, want de Maleier houdt er van den Dajak te bedriegen. In andere gevallen weer zijn het stukjes hout, die in den droom zijn aangewezen en die bij maansverduistering gehaald moeten worden. Weer in andere gevallen zijn het zonderling gevormde takjes of grasjes.

De karoehai's dienen alleen voor speciale gevallen, er zijn er die slechts in den handel geluk brengen, weer andere die 
den man bij de zwakke kunne een onvergelijkelijk succes zullen doen hebben, een derde categorie pleegt men te bezigen bij het dobbelen, hetzij om zonder meer geluk te hebben, hetzij om bij valsch spel niet ontdekt te worden. Die welke ik het meeste leerde kennen waren echter de z.g.n. karoehai hadjawet, middelen waarmee men zich tot een groote rotanvlechtster makkt. Mij zijn ter zake drie middelen bekend, die mij als diep geheim zijn meegedeeld. Deze karoehai hadjawet zijn familieof liever gezinsgeheimen. De beste vlechtster van Beneden Dajak pleegt daartoe te gebruiken afkooksel van sereh, dat ze op de nagels van haar rechterhand smeert. Dit middel moet reeds jong aangewend worden, reeds als de kinderen de eerste wankele stappen op het gebied der kunst zetten; het wordt later bij tijd en wijle nog eens herhaald. De tweede kunstenares, gesproten uit de familie Djata, gebruikt sawang-bladeren gemengd met koenjit, hetgeen een dag koken moet en daarna wordt gebruikt. De ingrediënten moeten bij nieuwe maan ingezameld worden.

Beide deze meisjes worden herhaaldelijk lastig gevallen met verzoeken om hun geheim te verraden. Een andere toepassing dezer middelen, die in dat geval echter slechts de strekking hebben om een goeden prijs voor de matten te maken, is om kleine grassprietjes in de mat te vlechten. Men treft in zulke gevallen veelal als randmotief het motief rear (geld) aan, waarbij het aantal afgebeelde realen dan den prijs voorstelt dien ze zich hopen te verwerven. Waar de rand aan de lange zijde veelal twintig, aan de korte \pm tien rear-afbeeldingen draagt, zou het zestig realen zijn, $f 120$.- Bij een gewone mat van de gewone afmetingen loopt het echter veelal op zestig kwartjes uit ( $f$ 15.-).

Een andere soort vormen de penjang. De voornaamste penjang's zijn die welke oudtijds moed gaven bij het koppensnellen. Ze hangen aan den mandau en vormen daarvan een voornaam versiersel. Veelal bestaan ze uit popjes van hout, dat den drager in droomen of op andere wijze is aangewezen. Zulke stukjes hout noemt men, als ze nog niet bewerkt zijn, bambang. Ook dat zijn voorwerpen als krom gegroeide houtjes, stukjes bamboe, galiga steenen, steentjes enz. Men bindt ze tezamen tot een bundel (zoo zag ik ze aan de Boven Katingan) of men sluit ze in bamboe-bussen met een stop, waarop een menschenfiguurtje met groote schaamdeelen is afgebeeld (Kota Waringin, Boven Dajak). Ook de karoehai's pleegt men zoo op te bergen. 
Een der voornaamste welke ik zag is die, welke eigendom is van den mantir Poeloehan van Petarikan (K.W.) en die den specialen naam draagt Penjang Mangkoe Raja. Deze bestaat uit de volgende voorwerpen. Op een zeer kleine gong (pandi) liggen een dohong (tweesnijdende dolk) en drie penjang-bussen, met galiga's en steentjes uit krokodillen gehaald. Het voorwerp is "rịkssieraad" des Poeloehans en gaat aan de opvolgers over; het doet thans dienst bij doodenfeesten (ajah), de erfgenaam wordt er zeven maal mede aangeraakt. Vroeger, toen het snellen in deze aangelegenheid noodzakelijk was, zal het waarschijnlijk den zin hebben gehad op die wijze de ziel der snellers te versterken, wat ook uit het bijten op de dohong nog blijkt.

Voor een Dajaksch huis zijn ten allen tijde talrijke voorwerpen te zien, die tot afwering van booze invloeden dienstig zijn, en in het bijzonder tot wering van ziekte; het zijn krokodillen eieren, orang hoetan schedels, uit riet gevlochten popjes en dergelijke.

\$59. Sial en de bescherming daartegen.

Hebben we boven gezien, welke hoogere wezens en geesten de Dajak kent, en hebben we nagegaan op welke manier men zich van de hulp dier goden en geesten middels bezweringen kan verzekeren; hebben we tevens kennis gemaakt met voorwerpen, die bijzondere gaven aan den drager kunnen geven, thans rest ons nog de behandeling van een toestand, die in het primitieve leven van zeer veel beteekenis is, n.l. de toestand van sial. De vertaling van dit woord door ongeluk geeft niet juist de beteekenis weer; het sial ontstaat doordien men ten nadeele van iemand iets doet, wat niet volgens de adat is.

Niet de overtreder komt in sial-toestand, maar de persoon, die de handeling raakt. Dit verwekken van sial is een der zuilen van het Dajaksche strafstelsel; zooals we later zullen zien is de Dajaksche straf, behalve vergoeding voor een materieel nadeel, ook een vergoeding om het sial te bezweren.

Alles kan in sial-toestand komen, zoowel de mensch als een voorwerp, ook de grond.

Eenige voorbeelden kunnen gelden ter opheldering.

$a$. Indien iemand twist maakt met een ander en hij hakt in de palen van zijns vijands huis, dan is de dader strafbaar en moet manjak of badap sangkolan betalen. Indien deze 
bezwering niet gehouden zou worden, is het mogelijk dat de sambalik (\$33) verstoord zullen zijn en den bewoner van het huis - dus niet den dader - met de gelijknamige koortsen zullen lastig vallen.

$b$. Indien in een kampong jaarlijks meerdere personen sterven, verlaat men den bewusten grond, omdat de oerai van die plaats niet goed gezind zijn; men noemt zulken grond tanah sial.

c. Als een muis in een matras zijn woonplaats opslaat, mag men daarop niet meer slapen; den slaper zou een ongeluk treffen, hij zou in een toestand van sial komen en ziek kunnen worden.

d. Legt een persoon bij eens anders batang aan, en zakt hij door dit vlot heen, dan wordt de eigenaar beboet, omdat de aangekomene in een toestand van sial door dit voorval is geraakt.

De kwade invloeden worden dus op verschillende manieren opgewekt, òf doordat het resultaat een ongelukkig omen is (voorbeeld $d$ ) ò omdat de boosheid van hoogere wezens wordt opgewekt (voorbeeld $a$ ), dan wel doordat de goden blijken verstoord te zijn, zonder dat men daarvoor een reden kan noemen (voorbeeld $b$ ).

Deze toestand van sial is voor den Dajak wel de meest gevaarlijke van alle rampen, die hem van hooger hand bedreigen. Het is dan ook natuurlijk, dat zich hiertegen nog een bijzonder stelsel van beschermende maatregelen heeft ontwikkeld, die in de dagelijks voorkomende gebeurlijkheden de menschen tegen sial-invloeden moeten beschermen. Deze afwerende middelen zijn behalve de reeds bovengenoemde, de pali- of verbodsbepalingen. Door deze voorschriften hoopt men hen die door omstandigheden vatbaar zijn om in sial-toestand te komen, daartegen te beschermen, en ook de gevaarlijke gevolgen van daden, te verrichten door den mensch die in een bijzonderen toestand is, te voorkomen.

Wat dit laatste betreft komen de gevolgen van het opwekken van sial zeer overeen met de consekwentiën der bezwering door sympathie. Een zwangere vrouw bijvoorbeeld, die met de armen gekruist voor de borst zou zitten, heeft daardoor kans, dat het kind, dat zij ter wereld moet brengen, als het ware in haar lichaam wordt vastgebonden en dus als de tijd der bevalling daar is, niet zal te voorschijn komen. De vrouw is daardoor in sial-toestand gekomen en zal middels de bezwering van het "manjaki» zich moeten zuiveren.

De Dajak die voor ziekte is behandeld verklaart zijn huis voor drie dagen pali (panti K.W.), omdat het te vreezen is, dat 
bij het zien van vreemden, de weer terug bezorgde ziel opnieuw de wijk zal nemen.

Het verbreken van een dusdanig pali wordt evenzeer - zooals we later zullen zien - gestraft. Bij de verschillende gebeurtenissen in het menschelijk leven zullen we met tal van die voorschriften kennis maken, en zullen we tevens verschillende uiterlijke teekenen van het pali leeren kennen. Bij de te noemen straffen zullen we ook nagenoeg steeds weer moeten vermelden, dat bij de strafbepaling de badap sangkolan, of manapas pali (wegvegen van het pali) moet worden betaald.

De sial-toestand doet hem die in dien toestand komt, vatbaar zijn voor een bepaald ongeluk (meestal ziekte), welk ongeluk bezworen kan worden door het manjaki (basangkolan); dan wel men kan voorkomen het sial op te wekken, door zich te houden aan de geldende pali-voorschriften. De veronachtzaming doet de machten van Radja Sial (\$28) losbarsten.

$\$ 60$. De ziel en hoe men op de ziel invloed kan krijgen.

In $\$ 27$ zagen we dat de penjaloempak der menschen in staat is het lichaam te verlaten. Het is nu mogelijk dat anderen op die ziel invloed krijgen, hetzij door ze te vangen als men ze toevallig tegenkomt, hetzij door een bezwering te houden, waardoor men in staat wordt gesteld op grooten afstand dit levensbestandeel des menschen, en daarmede natuurlijk den persoon zelve, te benadeelen.

We moeten dan allereerst in eenige nadere beschouwingen treden aangaande eenige lichaamsdeelen en andere tot den mensch behoorende namen enz., en hun beteekenis voor den persoon nagaan. Indien vijanden de bovenbedoelde bezwering wenschen te houden, zullen ze daartoe een pop maken, die zoo mogelijk een stukje nagel of wat haar van den te benadeelen persoon bevat. Daardoor acht de bezweerder een deel der ziel in de pop omsloten te hebben, of althans een bezwering door sympathie gemakkelijker te bereiken. Het is dan ook strafbaar gesteld eens anders haren te verbergen.

Even nauw is de connectie tusschen menschen en hun naam. De naam wordt geacht in zeer nauw verband met den drager van dien naam te staan; door het zelf uitspreken van den naam geeft men den toehoorder macht over zich. Dit geldt evenzoo Dl. 80 . 
voor vader en moeder. Om nu te voorkomen dat men zoo zich zelf groot nadeel zal doen, is het uitspreken der eigen naam of dien der ouders pali. Ook voor de ouders zelve is het pali den naam der kinderen te noemen. Men zal in de Dajak-landen reizende, dan ook nooit uit den eigen mond des gevraagden persoons zijn naam vernemen, steeds zal hij een ander vragen voor hem te willen antwoorden. Is er geen andere persoon dan zal hij kort weg een valschen naam opgeven, of naar waarheid "pali» zeggen. Roept een Dajak iemand, die denzelfden naam draagt als hij - dus als het pali is dien naam uit te spreken dan zal de Ngadjoe en de Ott Danoem dien persoon aanroepen met "Antai». De Maleiers van Kota Waringin gebruiken dan: warang sanama, sangarang; roept men als iemand, die denzelfden naam heeft als b.v. de vader des roepers, dan zal deze roepen ‘pangantai amai» (O. D.)

Van het haar is bekend, dat dit ook bij andere bezweringen gebezigd wordt. We zullen het later tegenkomen als offer bij de eerste aanraking met de aarde, en bij het doodenfeest. In het eerste geval verpersoonlijkt het den persoon zelve, terwijl hij aan de oerai wordt voorgesteld.

Gaan we thans na hoe de bezwering toegaat, waarop we boven zinspeelden, het z.g.n. sadiri. De bezweerder gaat voor de pop zitten en prikt daarin met spelden of roostert het voorwerp, daarbij voortdurend bezweringen uitsprekende. Het origineel der pop zal nu, hoe ver ook verwijderd, aan dezelfde pijnen bloot staan als de beeltenis.

Een dergelijk geval werd mij onder meer eens verteld, als gebeurd in de kerk van Koeala Kapoeas. Een jong meisje, dat een minnaar had afgewezen, werd op grooten afstand door dezen het navolgende leed berokkend. Hij had een pop gemaakt en deze aangekleed, waarna hij middels bezweringen op allerlei min oirbare plaatsen gaten makte in de kleeren der vrouw; het gevolg was dat het meisje, dat juist ter kerke was, tot de onaangename ontdekking kwam, dat in haar Zondagsche kleeding op bedoelde plaatsen gaten vielen.

Dit geval is een der meest opzienbarende geweest in Beneden Dajak, en met geen mogelijkheid kan men de menschen van de onmogelijkheid ervan overtuigen. Het is echter een geval dat betrekkelijk geringe gevolgen heeft gehad; talrijk zijn echter die, welke met ziekte en dood eindigen. Men zal bij ziekte-bezweringen 
dan ook allereerst overgaan tot een manjaki om deze eventueele invloeden te bezweren. Helpt dit alles niet, dan verandert men ook wel van naam.

Ditzelfde heeft plaats als men in sial-toestand is gekomen doordat een krokodil naar dezen persoon in kwestie gehapt heeft. Dit is geen gulzigheid van dat dier, maar hij heeft het op last van zijn heer en meester (Djata) voorzien op een bepaald mensch ; door nu zijn naam te veranderen, maakt men het dier het spoor bijster.

\section{$\S 61$. Weerwolven.}

Het zij hier even medegedeeld, dat krokodillen eigenlijk heelemaal geen dieren zijn, maar menschen die in de veischillende rijken der Djata's wonen. De poorten dier landen liggen in de diepe rivierbochten (labehoe's). De beschrijving der dorpen van Djata worden door "ooggetuigen» gegeven, als geheel gelijk aan die der menschen. De krokodillen-vachten liggen, als de prauwen der Dajaks, aan de batang; willen ze vertrekken dan kleeden zij zich daar in.

De gevangen menschen worden in hokken opgefokt, evenals geiten en varkens.

Dit speciale ras der weerwolven komt ook bij andere diersoorten voor. We zien herten, katten, honden en dergelijke, die bij tijd en wijle menschen zijn. Dit is echter een andere soort dan die der bovenvermelde krokodillen. We hebben hier te doen met "verdoemde» menschen. Het verhaal draagt zich meestal als volgt toe: een boschproductenzoeker komt in een leeg huis, de menschen zijn ter ladang, maar aan den muur hangen hondenvellen, waardoor het hem duidelijk wordt, met weerwolven te doen te hebben. Door het verbranden der huiden zijn de menschen gedoemd steeds mensch te blijven.

Talrijk zijn de verhalen hoe gevangen visschen kinderen blijken te zijn; men voedt ze op, maar ze zijn op hun beurt weer verwekkers van menschen, die naar believen visschenvel kunnen aantrekken. Afstamming van honden wordt den Semboeloeërs verweten; of zij tot heden toe van vel kunnen verwisselen werd mij niet meegedeeld.

Gevaarlijk zijn de weerwolven niet; het is meer nadeel voor hen zelve, om zoo af en toe tot dieren te moeten afdalen, dan voor de gemeenschap. 


\section{\$ 62. Invloed op de natur.}

Waar we met een samenleving te doen hebben, die zoo zeer achter elk gebeuren den invloed van bovennatuurlijke wezens zoekt, en die ten volle in de overtuiging leeft, dat ze door haar doen en laten de goden en geesten kan beïnvloeden, en hen kan drijven in den lijn, dien zij gaarne gevolgd zouden zien, daar behoeft het niet te verbazen, dat aangaande de natuurkrachten, die op verschillende tijdstippen van zooveel belang zijn voor hunne werkzaamheden, gewoonten zijn ontstaan, die de strekking hebben een en ander naar eigen wensch te regelen.

Beginnen we dan met den regen te beschouwen.

Nadat het veld voor den landbouw in orde is gemaakt en de rijst is gezaaid, is het noodig dat een flinke regenbui de planten drenkt. De plant heeft veelal eind Augustus, begin September plaats, behalve als de voorteekenen slecht zijn, in welk geval men tot October kan planten. $\mathrm{Nu}$ gebeurt het wel dat de Westmoesson dan nog eenigen tijd op zich laat wachten, waardoor het zaad dreigt verloren te gaan; men houdt dan èen regenbezwering. Aan de Saroejan wordt daartoe op de steenen van een stroomversnelling een stok opgericht, waaraan van boven een hoeveelheid gras en haar is bevestigd. Dit wordt in brand gestoken, en middels den rook (wolken) en de opspattende waterdruppels der stroomversnelling, worden de Djata's (de regenverwekkers) opgewekt tot het verwekken van regen.

Aan de Kota Waringinsche rivieren houdt men de bezwering middels een toeba-partij, waartoe het geheele stroomgebied door den mantir poeloehan wordt opgeroepen. Het wit melksap zou de wolken voorstellen, het geplas en geploeter, dat noodzakelijk gevolg is van het vangen der visschen, stelt den regen voor. We zien dus dat dit alles op bezwering door sympathie berust. Gaat het nu echter te veel regenen, dan brengt dat evenzeer de velden in gevaar. De jonge planten zouden door den bandjir kunnen verdrinken. Men stelt daartoe in het Katingansche een z.g.n. balei taloeh op, die juist daar staat waar het water den hougst mogelijken stand inneemt, zonder de gewassen te schaden. Niet alleen wordt door de kamponghoofden daar bij het begin van den planttijd een offer gebracht, doch dit wordt herhaald zoodra de stand der rivier van dien aard is, dat vrees gerechtvaardigd is. Deze balei's bevinden zich bovenstrooms 
van de kampong; eenige malen constateerde $\mathrm{ik}$ dat de plaats dezer balei tevens de grens tusschen twee kampongs was. De offers worden natuurlijk aan de Djata's gebracht.

Ik maakte op mijn reis de zonsverduistering van 21 September 1922 mee. Het maakte op de bevolking nagenoeg geen indruk, een weinig werd er op de gong geslagen, maar lang niet in die mate als in 1920, toen ik een maansverduistering in Beneden Dajak beleefde. Onder helsch spektakel werd toen op rijstblokken, gongs, huispalen enz. geslagen.

Men verklaarde een en ander, als zou de maan door een kwaden geest worden aangetast; het rumoer diende om de maan behulpzaam te zijn, en niet zonder voldoening keerde men na afloop naar zijn matje terug, vast overtuigd als men was, de maan aan zich verplicht te hebben. Welke geest de schuldige is kon mij niet verteld worden.

\section{HOOFDSTUK III.}

\section{Zwangerschap en bevalling.}

$\$ 63$. Het tooneel van het leven; het dorp.

$\mathrm{Nu}$ in het voornemen ligt, het leven van den Dajak in alle deelen na te gaan, moeten we ons allereerst een voorstelling maken van het tooneel, waarop zich dit leven afspeelt: het dorp. De hier volgende uiteenzetting zal gelden de hoofdvestiging van het dorp; de verschillende verspreid staande huizen zal ik buiten beschouwing laten, omdat het leven der bewoners daarvan in niets verschilt van dat der eigenlijke dorpsbewoners, en geheel met dit laatste samen gaat.

De oude vorm der vestiging, het familie-huis — de betang is nog slechts in de hoogste bovenlanden aan te treffen en ook daar reeds zijn ze veelal maar ten deele bewoond. De Dajaks van Boven Dajak houden nog het meeste vast aan die oude adat, maar wonen nog slechts met drie of vier kabali's samen, die elkaar meestal zeer nauw bestaan; verder kunnen we nagenoeg zeggen dat de Dajaks van Zuid Borneo in gezinshuizen wonen. Een betrekkelijk gering aantal van die woningen - de grootste Dajaksche kampong die ik gezien heb is Koedangan (K.W.) met \pm 1300 inwoners - vormt de vestiging. Ze staan in een korte rij langs de rivier of het riviertje. Hierop vormen 
de Mamah Darat van Kota Waringin een uitzondering; het stroompje waaraan zij hun dorp bouwen is zóó klein, dat het slechts als mandi-plaats kan dienst doen; voor verkeersweg wordt het niet gebruikt. $Z \mathrm{ij}$ hebben hun dorpen aan weerszijden van de voetpaden die hun gebied doorsnijden.

In de rivier treft men de badvlotten aan (djamban, batang), waar men tevens allerlei andere huishoudelijke zaken verricht, als wasschen van vaatwerk enz. Langs de rivier loopt een weg en daaraan staan, $\pm 10 \mathrm{M}$. landwaarts in, de woningen, omgeven door vruchtboomen, knolgewassen enz. De huizen zelf zullen later beschreven worden.

In het midden van het dorp treft men de «balei, aan, de woning, waar de reizigers worden ondergebracht, waar men tot besprekingen samen komt, en waar ook sommige feesten gevierd worden, zooals we later zullen zien. Deze balei worden door de kamponggenooten gebouwd en onderhouden. Veel vermeldenswaard is aan de balei niet te zien. Alleen staat vaak de blaasbalg (gagoelang) - meestal is er maar één in een dorp - onder of bij het dorpshuis. We zullen later hierop terug komen.

Voor nagenoeg elk huis ziet men, rechts als men de trap afkomt, een boschje sawang-boomen, teekenen van huwelijksfeesten of een der vroeger genoemde bezweringen vormende. Men pleegt daaraan nog al eens een offermandje op te hangen. Verschillende woningen hebben voor dat doel een klein baleitje naast dit boschje staan.

We zagen reeds vroeger, hoe in het Kota Waringinsche elk dorp zijn oempan laman of panggoel laman (dorpsofferplaats) heeft, niet ver van de woning van het hoofd, waar deze op gezette tijden offert en ook een offer brengt indien er feest ter plaatse is. Elders zien we in plaats van het sawang-boschje, de patahoe, een steen, of een balei met eenige steenen erin, ook alweer omgeven met de heilige planten.

Ten slotte vallen in elk Dajaksch dorp of in ieder voormalig dorp, de overblijfselen op van de doodenfeesten, die eenmaal daar zijn gehouden. Het zijn de pantars, sandoengs, hampatongs, sapoendoes enz., allemaal zaken, die we later bij de begrafenisgebruiken nader zullen leeren kennen, voorwerpen, die het kenmerk vormen van de Dajaksche vestiging, en die in geen kampong der bovenlanden gemist worden. 
Een andere belangrijke bezienswaardigheid vormen de trappen, die van de djamban naar den weg voeren. Het zijn - althans de echte - zware ijzerhout-boomen, waarin inkeepingen zijn aangebracht. Het boveneinde wordt gevormd door een afschrikwekkend menschenhoofd, met groote slagtanden. Deze af beelding doet dienst als afschrikking voor de booze geesten, die anders de trap zouden bestijgen en onheil veroorzaken. In vele gevallen ziet men de trap nog beschermd door menschenbeelden. Zijn deze aanwezig, dan vertoonen ze veelal ontbloote schaamdeelen, het mannelijke lid is meestal in erectie afgebeeld. De strekking dezer vertooning is evenzeer de wering van booze geesten.

Het is een zeer gebruikelijk middel om kwade invloeden af te weren, door den duim tusschen wijs- en middelvinger te brengen, en indien ernstig gevaar dreigt, is een goed middel zich te ontkleeden. Speciaal het zien van vrouwelijke schaamdeelen is voor mannen een teeken van sial. Zoo hooren we de Dajaks der Boven Kapoeas een geschiedenis vertellen van zekere Niai Boela, een slavin, die een asang-tocht tegen haar kampong deed mislukken, door zich naakt aan den vijand te vertoonen, die daarop overhaast terugtrok, omdat dit een teeken van sial was. Niai Boela zou daarna hoofd geworden zijn. Ook de Maleiers zijn deze meening toegedaan. Op een mijner reizen met mijn oppasser een klein riviertje passeerende, hoorde ik hem plotseling sial zeggen, en opkijkende zag ik een badende vrouw. De oppasser zeide mij, dat ze, toen hij haar zag, overeind stond, en dat hij toen hare geslachtsdeelen gezien had, hetgeen sial beteekende.

Toen hij zich een oogenblik later aan een stuk bamboe verwondde, achtte hij dit de schuld der vrouw.

We zien dan ook bij de Dajaks strafbepalingen (vijf keping) tegen de vrouw, die zoo onvoorzichtig is, een argeloos voorbijganger in sial-toestand te brengen. Meisjes die nog niet in de puberteitsjaren zijn, veroorzaken geen sial op deze wijze.

$\S 64$. Ideeën aangaande kinderzegen.

Het doel van het huwelijk is, behalve het verkrijgen van een helpster bij den arbeid, het bekomen van nageslacht, een en ander om der wille van den ouden dag, want de kinderen zijn verplicht de ouders te verzorgen, zoodra deze te oud zijn om te werken.

De Dajaksche vrouw acht het hebben van kinderen de hoogste 
zegen, die haar beschoren wordt; wel is waar wordt ze niet zooals elders wel voorkomt - veracht als ze geen kinderen ter wereld brengt, maar toch is het een grief der echtelieden. $\mathrm{Ze}$ zullen dan ook geen middel ongebruikt laten om tot het doel te komen, offers worden gebracht en beloften gedaan aan den machtigen Sangoemang en de Djata's. Het is me zelfs overkomen, dat men mij om middelen vroeg, die het daartoe zouden voeren dat steriliteit werd opgeheven.

Daarom is het te merkwaardiger dat er eenige streken zijn, waar de vrouwen zich kunstmatig voor ontvangenis niet vatbaar maken. Van de mij bekende streken waar dit misbruik sterk ontwikkeld is noem ik in de eerste plaats het stroomgebied der Mapan (K. W.). Hier is het een gevolg van den uiterst lossen huwelijksband; het is geen zeldzaamheid dat men daar vrouwen van een jaar of dertig ziet die reeds twintig tot vijf en twintig maal getrouwd zijn. Ze trachten zooveel mogelijk zwangerschap te voorkomen, omdat ze dan bevreesd zijn verstooten te zullen worden en geen nieuwen man te zullen krijgen.

Een tweede gebied is de Mantobi (K.W.) waar het echter meestal wordt toegepast nadat een of twee kinderen geboren zijn. De middelen die men daartoe aanwendt zijn velerlei. Allereerst geschiedt zulks door het drinken van afkookels van bladeren, andere aftreksels worden weer gebezigd om de vrucht - indien men zwanger is geworden - af te drijven. Een andere methode is die, welke ook wel door Javaansche vrouwen wordt toegepast. Op een bijzondere wijze wordt daartoe de onderbuik gemasseerd, waardoor naar het schijnt de baarmoeder wordt afgesloten. Het gevolg van een en ander kan echter gevaarlijk zijn, aangezien het tot maagkrampen aanleiding geeft.

De excessen daar gelaten, moet volgens de Dajaksche opvattingen de onvruchtbare vrouw - manang - als een ongeiukkig schepsel worden beschouwd. Zooals reeds gezegd, is, nadat men meerdere kinderen heeft gekregen, het nagenoeg algemeen gebruik de vrucht af te drijven.

Over het feit der bevruchting hebben de Dajaks geen bepaalde voorstelling, wel weten ze, dat de gebruikelijke oorzaak der zwangerschap de coitus is. Maar ook op andere wijze kan men bevrucht worden. Spoken kunnen zulks doen, maar ook kan men door het eten van vruchten in dien toestand komen. Aangaande het eerste geval zullen we later spreken; het laatste 
wordt in verschillende verhalen gemeld. $\mathrm{Na}$ het eten van vruchten werd een meisje zwanger, waarna een heele roman volgt, die in den regel daarmee eindigt, dat de man, die tegen den boom geürineerd heeft, waardoor zijn zaad in de vrucht is gekomen, haar ontmoet en met haar trouwt.

Asai Menteng, een der Sangiangs, zou uit de kuit van een Sangiang-man zijn geboren, waar omheen zich bij het baden een schaamhaar van een bovenstrooms badende vrouw geslingerd had. Het haar kon niet verwijderd worden, het been werd zwanger en de moedige Asai Menteng zag, toen de tijd daartoe was aangebroken, het levenslicht.

We zien dus dat op allerlei wijze bevruchting kan plaats hebben. Tevens acht men het mogelijk een vrouw op andere wijze te bevruchten, dan langs den gebruikelijken weg. Men acht het slechts noodzakelijk, dat het mannelijke zaad in het lichaam der vrouw wordt gebracht; wáár, is volgens hen van geen overwegend belang.

Gaan we thans het gewone geval na, dat een vrouw, na eenigen tijd gehuwd te zijn geweest, zwanger wordt; later zullen we het geval der afgebeden, kinderen en der onechte kinderen beschouwen.

$\$ 65$. De eerste teekenender zwangerschap; de bezwering.

Het voorgaande lezende zouden we denken, dat de eerste teekenen der zwangerschap met vreugde zouden worden begroet; dit is echter niet het geval, de eerste vier à vijf maanden gaan voorbij zonder dat men aandacht aan het geval schenkt. Het eenige, wat de vrouw moet doen, is van haar moeder een soelau garanoehing vragen, dit is een stel oorsierraden, dan wel, indien deze er niet zijn, van de moeder een ehet leenen. Dit is een buikband, die zwangere vrouwen plegen te dragen van af den tijd waarop de zwangerschap haar duidelijk is geworden; tevens wordt een levende kip gevraagd.

Anders staat het als de vrouw gedurende eenige maanden in dezen toestand is. We zien dan in de verschillende streken van Zuid-Borneo feesten houden, die alle min of meer verschillen, maar waarvan de kern bestaat uit een manjaki.

Gaan we eerst na hoe een en ander aan de Saroejan plaats heeft. Daar wordt na zes à zeven maanden het «badjaja pondok 
kapai» (Mal. palas boenting) gehouden. Men plaatst daartoe vier bamboes in den grond (poedjer), waartusschen een varken gehangen wordt. Onder dit varken nemen de beide echtgenooten plaats. Nadat de djaja's vóór dit geheel eenige malen hebben rondgedanst, wordt het varken doodgestoken en laat men het bloed over de echtgenooten heen loopen (mampondai daha oeah, baden in varkensbloed). Men heeft onderwijl een klein vlot (lanting) gemaakt, waarop zich eenige bordjes rijst enz. bevinden; miniatuur roeiers zijn er buitendien in opgesteld. De vrouw moet nu, na het mampondai, op het vlotje spuwen, waarna men het laat wegdrijven.

Men stelt zich voor, dat het vlot dan de kwade invloeden wegneemt, die misschien reeds op de vrouw hebben ingewerkt. Het speeksel toch staat in nauw verband met de ziel, men offert dit aan de watergeesten, opdat deze daarmee tevreden zullen zijn en niet de vrouw zelve zullen lastig vallen. Dit offer betreft niet de Djata, maar de booze watergeesten, die we in $\$ 29$ zagen ontstaan. Als een en ander is afgeloopen houdt men feest, waarna de pali-periode (pali is aan de Saroejan "pai») voor de echtgenooten aanbreekt. De eerste drie dagen is het hun dan verboden om in de rivier te baden. Bij dit feest wordt de vrouw een lamiang om de pols gebonden (lamiang kantas). De bij dit feest werkende djaja's krijgen als loon: een panding ( $\pm f 2.50$ ).

De Ott Danoems die nagenoeg hetzelfde feest hebben, noemen het malas kanei, malas boentoe of sahoi. De Sahiai Dajaks noemen het kortweg sahoer en volgen het bovengenoemde ceremonieel.

Bij de groote groep der Ngadjoe's zien we het volgende plaats hebben. Bij het manjaki (\$42) moet men in dit geval minstens één varken gebruiken, liefst echter een karbouw. Het gebruik brengt mee, dat als een karbouw geslacht wordt, noodzakelijk ook een varken als "bantalan " voor de karbouw gedood moet worden (K.W. laki); voor een varken vervult een hoen die rol.

Voor het manjaki nu is het noodzakelijk, dat een balai wordt vervaardigd. Hiertoe heeft men twee methoden, n.l. men maakt twee balai's, de eerste een balai samboeroep (de samboeroep zijn vierkante scheepjes waarin aan de djata's of aan Radja Oetoeng of Sangoemang geofferd wordt), die men in de rivier laat zinken, en de tweede de «balai panti», die men in een 
boom ophangt. Beide hebben den vorm van schepen. In het tweede geval hangt men alleen de balai panti op. In de balai samboeroep plaatst men een z.g.n. hampatong sadiri, ook ganti diri geheeten ( $\$ 60$ ), welke men in de balai plaatst alvorens haar te doen zinken, en die het speeksel der Saroejan vervangt. De maleische naam doet ons duidelijk zien wat de beteekenis dezer pop is.

Hangt men de balai panti alleen op, dan is het noodzakelijk in een antjak, de hampatong sadiri in de rivier te laten zinken.

Nadat dit is afgeloopen, heeft het manjaki plaats, en in sommige families het mamboehoel ( $\$ 43$ ).

Men mag een en ander laten volgen door het blakoe oentoeng (§46). Een andere bezwering is een kalangkang sawang met sadiri te water te laten. In dat geval is het niet noodig te werken met de beide balai's. Bij deze balai-bezweringen moet men gebruik maken van balians; dit is voor de kalangkang sawang niet geoorloofd, men moet daarbij z.g.n. "karoengoets" gebruiken, d. z. lieden die godenverhalen zingen. Dit zijn tevens bezweringen, die tot de weinige behooren, waaraan geen tantoelak voorafgaat; als men blakoe oentoeng laat volgen, moet de tantoelak daarvóór gebeuren, evenzoo in het geval van manjaki. Na een kalangkang sawang is echter de verdere bezwering van het palas niet noodig, hoewel het aanbevelenswaardig is.

Trouwen twee personen als de vrouw reeds lang zwanger is, dan laat men de hier vermelde gebruiken achterwege en houdt alleen het tantoelak doehi ( $\left.\$ 33 \mathrm{~N}^{\circ} 2\right)$.

In het Kota Waringinsche zien we andere gebruiken. Is daar een vrouw drie tot vijf, of zeven maanden in gezegende omstandigheden, (ngantoeng) dan wordt de bezwering ngantoeng toentoeng gehouden; tevens wordt dan de vroedvrouw (bedan) aangewezen, die bij de verlossing haar hulp zal verleenen. Bij deze bezwering wordt slechts één kip geslacht, met het bloed waarvan de vrouw wordt bestreken (di basangkolankan). Men bindt haar dan tevens een touwtje van tongang-vezels om den pols waaraan een agaatkraal is bevestigd (het geheel heet sirau pamah lamiang). Dit laatste werk verricht het kamponghoofd, dat tevens de vrouw met nasi gangam bestrooid. Een en ander geldt als bekendmaking aan de gemeente, dat deze vrouw in pali-toestand is gekomen. Wie daarna met deze zwangere twist, vervalt in de boete "kelompatan tonggang», waarvan het bedrag afhangt van den 
stand der vrouw. Zij komt daardoor immers in sial-toestand. Aan de Saroejan is de betreffende boete "sakipalas» geheeten en bestaat uit een kip, een stuk ijzer, waarop de te bezweren persoon moet bijten om zijn ziel te versterken (pangkit soemangat), verder: sirau lamiang, een bord en een kommetje.

$\mathrm{Na}$ het ceremonieel hierboven aangegeven, komen de echtelieden in een toestand van pali, waarbij ze zich voor talrijke zaken in acht hebben te nemen, die vrijwel overal dezelfde zijn en die de strekking hebben, belemmeringen bij de bevalling zooveel mogelijk te voorkomen. Men moet alles voorkomen, wat zou kunnen voeren tot een sympathisch gevolg voor het kind. Niet alleen de vrouw, maar ook de man moet zich aan die pali-voorschriften onderwerpen, tot aan het tijdstip dat de nieuwe wereldburger het levenslicht aanschouwt.

Vermelding verdient nog het gebruik dat vaak de vrucht wordt afgedreven, omdat men vermoedt dat een of ander dier, meestal een slang, zich in het moederlichaam heeft gevestigd om daar het kind kwaad te doen. Vooral als de buik der vrouw buitengewoon dik wordt heeft dit plaats, bv. ingeval van tweelingen. Men noemt zulk een geval ngandoang.

\$ 66. De verbodsbepalingen.

De verbodsbepalingen zijn onderscheiden in verboden handelingen en verboden spijzen. De vrouw mag geen vleesch gebruiken van het wilde rund, stekelvarken, hert, slang, de taumanvisch, de kasa-visch, de baning; aaneengegroeide vruchten mag zij niet eten, ze zou dan tweelingen baren waarvan er één een hantoe zou zijn. Verder vallen er nog onder: de biawak, het wilde varken en de schildpad.

De verboden handelingen, die evenals de eerstgenoemde den naam pali, pai, panti of pantang dragen, zijn voor de vrouw het slapen op een matras, gevuld met het kaf van kleefrijst, welk vulsel ook het hoofdkussen niet mag hebben. Het gevolg zou zijn dat het kind in het moederlijf zou vastkleven. De vrouw mag haar slendang niet om het middel vastbinden, mag niet met de beenen gekruist zitten, mag armen en handen niet gevouwen houden, aangezien dit alles hetzelfde resultaat zou hebben. Ze mag 's avonds niet aan de rivier baden, want de watergeesten zouden haar benadeelen en het kind in het moederlijf dooden. Wil ze toch 's avonds een bad nemen zoo moet ze om zich 
heen asch strooien, daar dit de geesten op een afstand houdt.

De man heeft zich, wat de spijzen betreft, aan dezelfde panti's te houden. Verboden handelingen zijn voor hem het jagen op wild, het dooden van huisdieren, het kappen van levend hout, daar dit alles het kind voor de geboorte zou doen sterven. Hij mag niet met een parang werken, want dit zou het kind met een hazenlip ter wereld doen komen, en mag evenmin zijn parang slijpen. Hij mag geen rotan schoonmaken, want het kind zou dan met de beenen naar voren geboren worden, vuur mag niet aangelegd worden door hem of zijn vrouw, want dit zou het gevolg hebben, dat een gevlekt kind zou gebaard worden. De vrouw mag evenmin in de geopende deuropening der woning gaan zitten; het kind zou weigeren te verschijnen. Men mag niet het voorwerp waarmee men eetwaren, of iets anders, uit een vaatwerk haalt (een soort houten lepel), in dat vat laten staan, want het kind zou evenzeer in het moederlijf blijven. De man mag voorts geen gaten graven, niet met bindrotan of spijkers werken, geen getah of djerenang zoeken, een rijstblok mag hij niet maken; dit alles zou het vastbinden van het kind in het moederlijf ten gevolge hebben, en wat het laatste betreft dit zou voeren tot het verslinden van het kind door een boozen geest. Geen van beiden mag voorts jonge dieren slachten, of een dier dat zwanger is.

Zeer voorname bepalingen zijn ook die, welke de te gebruiken taal betreffen, waaronder vooral het schelden of vervloeken van de aarde, het water, vuur en wind genoemd moet worden. Dit is bij elken pali-toestand verboden, omdat men daarmee zichzelf vloekt ; immers de aarde wordt vergeleken met het vleesch, het vuur met het bloed, het water met het leven en de wind met den adem.

Deze steeds wederkeerende verbodsbepaling noemt men de oepoen pali (de stam van het pali).

Zoo mag men ook niet spotten met dieren, metalen of andere imponeerende zaken, daar ook dat ongeluk over het kind zou brengen. Ook in andere gevallen brengt dit zijn gevaren mee. Immers de Dajak ziet alles in het licht, waarin hij zichzelve ziet. Belachelijk maken nu, iets wat hem "maloe» maakt, is het verschrikkelijkste wat er voor hem bestaat; maakt men nu andere wezens of zaken belachelijk, dan zullen ook die zich wreken, want zoomin als de Dajak zelve, zullen zij hun aangedane schande vergeten. 
Ook andere menschen hebben zich aan pali's te houden, zoodra ze in het huis der zwangere zijn. Ze mogen vanbuiten het huis de vrouw niets aanreiken. Ze mogen niet halverwege de trap opgaan en daarna weder terugkeeren, doch moeten daartoe eerst de woning binnengaan. Zijn ze eenmaal binnen, dan moeten ze bij vertrek denzelfden weg terugkeeren, het kind zou anders den weg naar buiten niet weten. In de vorige $\S$ zagen we reeds dat twistzoeken met de vrouw verboden is.

Indien vreemdelingen de pali-bepalingen schenden, vervallen ze in de boete saki palas, die, wat grootte betreft, afhankelijk is van den stand der zwangere vrouw. Hoe de man gestraft wordt zullen we later zien.

We zien uit het hiervermelde, dat het Dajaksche gezin zich aan allerlei bezwarende bepalingen heeft te houden om zich te dekken tegen aanvallen van hooger hand.

Behalve al deze pali's beschermt de vrouw zich nog op andere wijze tegen de invloeden die door booze geesten: kemiah of pojang, op haar kunnen worden uitgeoefend. Bij haar slaapmat hangt ze na de zevende maand een rijstoffer op, dat daar blijft hangen tot de bevalling. Men ziet daarbij dan meestal, dat, althans als de vrouw voor het eerst bevalt, een belofte gedaan wordt om, als de verlossing vlot afloopt, een of ander offerdier te zullen slachten. Dit offerdier wordt dan ook bij het manjaki gebruikt, van dit dier neemt men wat bloed om de vrouw te bestrijken. De kip, het varken of rund wordt daarna verzorgd en als de belofte vervuld moet worden, geslacht. Men noemt zulke dieren ajam- of babi sangkolan (palas). Indien een ander zulk een dier slacht of doodmaakt, maakt hij zich schuldig aan een strafbaar feit, en zal daarvoor beboet worden met bosi sebelas kepala tadjau, een kip en een stuk ijzer; de beide laatste noemt men badap sangkolan.

$\$ 67$. De bezweringen bij niet voor ontvangenis vatbare vrouwen.

Blijkt een vrouw niet voor ontvangenis vatbaar te zijn, dan stelt ze in heilige boschjes of aan labehoes offers op; respectievelijk voor Sangoemang en Djata. Aan deze offers is verbonden een gelofte om een groot feest te geven (meestal een balian hai), als het verzoek wordt ingewilligd. Tevens stelt ze naast haar slaapplaats een offer op, bestaande uit een koperen bak met 
rijst, waarin een klapper gelegd wordt. Zoodra de vrouw zwanger wordt, plant ze den klapper; deze klapper is ten nauwste verbonden aan het toekomstige kind, en beschadiging daarvan is, evenals vernieling van sawang-boompjes, strafbaar. Na de bevalling wordt dan de gelofte ingelost.

Men acht het in zulke gevallen gunstig als na verloop van eenigen tijd een slang in huis komt, men zal deze dan niet verdrijven, alvorens haar wat eten te hebben voorgezet. $\mathrm{Zij}$ wordt toch geacht de vrouw voor ontvangenis vatbaar te maken, of misschien beter, zij vertegenwoordigt een zieltje dat weder geboren wenscht te worden. (Zie bij de doodengebruiken).

\section{$\$ 68$. De geboorte.}

Het tijdstip der bevalling is uiterst gewichtig; alles wordt aangewend om de vrouw te beschermen tegen de in drommen aanrukkende kwade geesten. Allereerst wordt aan den zolder van het huis een net opgehangen, hetgeen hantoeëns en pojangs afschrikt; vóór de deur worden limau-bladeren gebrand, waarvan de rook alleronaangenaamst is voor booze geesten.

Het huis wordt pali verklaard, hetgeen kenbaar is doordat men een sawang-blad in de deuropening hangt (Sahiai) of door een rotan, waaraan limau-bladeren hangen, vóor de huistrap (Saroejan).

Verbreken van dit panti wordt gestraft met bosi sabelas kepala tadjau, benevens badap sangkolan; het panti noemt men in dit geval in K. W. roengsoeng toenggoei. De Sahiai Dajaks straffen een en ander met één djipen.

Zulke teekenen noemt men gagawar (K.W.) of batang pali (Ngadjoe). De vrouw moet verder haar haren losmaken; alles wat in huis is vastgebonden wordt los gemaakt, evenals de voorwerpen die in zakken of scheeden zitten.

De eenige personen, die in het huis mogen zijn, zijn de familieleden en de helpsters: bedan, njahata (Sahiai).

Woont men in een familiehuis, dan wordt alleen de priok (lawang) van het gezin in kwestie pali verklaard, niet het geheele huis.

Bij de bevalling zit de vrouw met opgetrokken, uit elkaar gespreide beenen, leunende tegen een kist of paal, met het gezicht naar de deur; dit laatste opdat het voor het kind gemakkelijk zal zijn den weg naar het licht te vinden. De bedan 
neemt het kind van voren aan. Bij de Ott Danoems zit de vrouw op een plank, welke den naam siroe draagt.

In de meeste gevallen is de bevalling van een Dajaksche vrouw een kwestie van oogenblikken; komen er echter ernstige belemmeringen voor, dan gaan de bekwaamheden der helpsters niet zoo ver, dat ze werkelijke hulp kunnen verleenen en het lot der kraamvrouw is dan beslist.

De bedan (ngamin anak, Ott Danoem) werkt in den regel met drie helpsters (oloh mentang, mentang $=$ het dragen van een kind in een slendang, entang; de Sahiai Dajaks noemen die helpsters mohong, de Ott Danoems mendahop), die bij de bevalling de vrouw masseeren.

Zien we thans hoe de normale geboorte plaats heeft.

Het vruchtwater (toeban Maleisch) tetoepen (Sar.) sarat danoem (Sah.), heeft geen beteekenis, men laat het wegvloeien zonder er eenige aandacht aan te schenken. Als het kind verschenen is, wacht men tot ook de nageboorte (taboeni) - de jongere broeder of zuster der geborene - te voorschijn komt. Is deze niet genegen te verschijnen, dan beteekent dat de dood van de vrouw. Slechts enkele gevallen noemde men mij, dat na verloop van eenigen tijd de nageboorte bij stukjes en beetjes te voorschijn kwam, en zoodoende de vrouw in leven bleef.

Middelen om een vergroeide nageboorte uit het moederlichaam te verwijderen kent men niet.

Is een en ander adn den dag getreden, dan wordt kind en nageboorte op een pinang-scheede gelegd, en de bedan maakt zich gereed tot de volgende werkzaamheden. Dit is n.l. het doorsnijden van den navelstreng (manotas, K.W.), (natak poesot, Sar.).

Alvorens daartoe over te gaan wordt eerst het gezichtje van het kind afgewasschen.

De navelstreng wordt doorgesneden met een mesje van bamboe sambiloe, hetwelk op een zilveren munt snijdt, of op een stuk poelai- of palara-hout. Voordat gesneden wordt raakt men eerst den navelstreng met de dohong, of pisau raoet aan; men mag daarmee echter niet snijden, want dit moet met het bamboe werktuig gebeuren. Bij het doorsnijden moet men eerst den navelstreng uitdrukken vanaf de taboeni naar het kinderlichaam toe. Men noemt dit nemaroet poeser (Ngadjoe) narisit (Sah.). Dit dient daartoe, dat men de restjes levensgeest, die in de nageboorte huizen, in het kind overbrengt. Men moet een en ander 
voortzetten tot de taboeni niet meer beweegt. Daarop bindt men deze af middels tali tongang, en snijdt hem vervolgens door.

De munt of het stuk hout hebben een verschillende bestemming. Bij de Ngadjoe's en Sahiai's waar het muntstelsel heerschende is, wordt dit geldstuk door de moeder bewaard, en bij voorkomende gelegenheden opnieuw gebruikt. In geval van bezweringen bezigt men het als batoe saki. Aan de Saroejan wordt het palara-hout verbrand en op de wonde van den navel gesmeerd, die daardoor spoedig verdroogt. De Mamah Darats daarentegen bewaren het poelai-hout; de moeder bergt het onder haar hoofdkussen op, en gebruikt het bij voorkomende gelegenheden opnieuw. Indien ze zwanger is, draagt ze dit stukje hout in haar buikband.

In sommige streken, bijv. Beneden Dajak, is de bedan in staat uit de uiterlijkheden der taboeni de gelukkige of ongelukkige toekomst van den jongen wereldburger te voorspellen.

Direct na de bevalling mag de bedan zich een nieuwe soeloi of sarong aantrekken; wat een harer wettige emolumenten is.

De nageboorte wordt in een bamboe mandje (kaboel, koesah Sah.) gelegd; aan de Saroejan wordt de taboeni van een jongen in zeven laagjes kladi-bladeren verpakt en daaromheen zout gelegd. Elders treffen we slechts conserveering middels zout of koenjit (mantobi) aan. De bakoel wordt vervolgens even tegen het hoofd der moeder aangehouden (dit noemt men sri boenga poendjoeng, K.W.), om daarna de voor haar bestemde plaats te krijgen. In het geheele Ngadjoe-gebied is deze plaats onder de huistrap, waar ze in den grond wordt begraven. Aan de Boelik begraaft men de taboeni onder de slaapplaats van de vrouw. De Saroejan Dajaks hangen de bakoel aan een boom, die zoo dicht mogelijk staat bij de kookplaats; de Sahiai Dajaks hangen de koesak aan den buitenwand van het huis, tegen de plaats waar de vrouw pleegt te slapen.

We dienen nu na te gaan wat de beteekenis is van een en ander. De ziel der taboeni wordt geacht een bestanddeel te zijn van de vrouwenziel. Keert die ziel na een bevalling niet in het moederlichaam terug, dan is de vrouw verder niet meer vatbaar voor ontvangenis.

Daarom zoekt men als begraafplaats steeds een plek uit, waar de vrouw vaak voorbijkomt of vertoeft, opdat de ziel gemakkelijk kan terugkeeren in het lichaam.

Dl. 80 . 
Veelal wacht men met het begraven - althans in de Ngadjoe streken - tot het naveltje is afgevallen en daarmee het pali der barende is opgeheven. Inmiddels wordt dan de bakoel met een brandend lampje naast de slaapmat der vrouw gezet. Lacht de kleine wereldburger in zichzelve, dan zegt men dat hij grapjes makt met zijn jongeren broer(zuster). Huilt hij echter dan is dit een gevolg van een twist. Veelal zal men dan ook in dat geval de taboeni het verwijt doen, onaardig te zijn voor den broer(zuster).

Als de nageboorte in den grond wordt gelegd, wordt om het "graf» een hekje gemaakt van kleine ijzerhout-plankjes (padong poesot). In sommige streken onderscheidt men de meisjes-taboeni van die der jongens, door respectievelijk vijf of reven plankjes te gebruiken.

Op andere plaatsen (Mantaja) riet men kleine balkjes binnen de pagar poesat liggen.

Vernieling dezer ommuringen is strafbaar; de kleine zou immers daardoor in sial-toestand komen evenals de moeder. De bedreigde boete is een losa.

$\mathrm{Bij}$ de opgehangen bakoel zien we dat den eersten tijd het leven van het kind en dat van de taboeni nog op elkaar inwerken. Wordt toch deze laatste door wormen aangetast, dan zal het kind ziek worden, daarom wordt deze bewaard in overvloedig zout.

Het naveltje valt meestal na een dag of drie af. Het wordt dan in het huis bewaard, een jongensnaveltje in een bamboe geleding: taboeng (tambarang Sah.), een meisjesnaveltje met koenjit in een stukje goed gepakt. De Sahiaiers maken dit onderscheid niet, maar verpakken den navel in kapok, waarna het geheel in de tambarang wordt gedaan.

Ook de navel heeft beteekenis voor het later leven. In geval van ziekte toch worden kleine stukjes in het voedsel van het kind gemengd. Ongeveer na twee weken worden eenige snippers genuttigd; ook de moeder eet dan daarvan een weinig (manjipa poeser). Dit valt meestal samen met het manahoenan, tenzij de gewoonten der betrokken familie meebrengen, dat het eten van den navel plaats heeft als het kind staan of loopen kan.

We moeten nu terugkeeren tot de bevalling en nagaan wat verder nog met het kind wordt gedaan. Ik zal daarbij de verschillende Dajakstammen afzonderlijk behandelen, omdat dan gemakkelijker de verschillen zijn aan te stippen. 


\section{$\$ 69$. Verrichtingen met de pasgeborene.}

Aan de Saroejan wordt, nadat de navelstreng is doorgesneden, het kind in huis gebaad (pondoei angsampakaja). Bij deze gelegenheid wordt het kind een lamiang kraal omgebonden, die evenals die, welke de moeder droeg van het manjaki, lamiang kantas heet. Dit baden binnenshuis komt ook elders voor. Daarna wordt de kleine tot aan de deur gedragen, waar men hem drie maal heen en weer wiegt, om het sial af te wenden.

Aan de Mantobi volgt men de volgende gebruiken.

Zoodra de navel is doorgesneden en het lind is afgewasschen, wordt het even dicht bij een vuurtje gehouden. Vervolgens brengt men het buiten, en heft het eenige malen omhoog. Binnenshuis terugkomende worden de nagels met pinang en sirih rood gemaakt, waarna de kleine wordt "gebasangkoland met bloed uit de kam van een levend hoen. Deze kip is manoek sangkolan, en mag niet geslacht worden.

$\mathrm{Na}$ dit ceremonieel heeft het baden bij de rivier plaats, dat elders eerst later gebeurt, bij de Maleiers b.v. den veertigsten dag na de geboorte. Bij de rivier aangekomen, werpt men één kraal in de rivier, en één op den oever; men acht het daardoor zeker, dat het kind door de bewoners van rivier en grond zal worden gesteund in dit leven.

Dit is de manier waarop de nieuwe deelgerechtigde in het beschikkingsrecht, den eigenaren van den grond wordt voorgesteld; het baden bestaat slechts uit het besprenkelen van het gezichtje met water.

Men keert naar huis terug, waar de spijzen reeds gereed staan, en waar men onder leiding van het dorpshoofd tot de naamgeving overgaat (\$ 70). Dit laatste heeft echter veelal eerst na het afvallen van den navelstreng plaats. Onder de spijzen behooren vooral de in bamboe gekookte rijst en vleeschsoorten. Is nu de bevalling geheel naar wensch afgeloopen, dan worden deze bamboes aan de klapperboomen opgehangen, opdat ook deze goed vrucht zullen dragen. Den daarop volgenden dag loopt de bedan driemaal met het kind naar een bepaalde plaats, meestal de oempan laman, soms ook een offerhuisje in de buurt, wat wederom een kennisgave aan de beschermgeesten van de bewoners van het voorgevallene is.

Men noemt dit gebruik mahoeroe boeloeh laloetoe. Daarna 
wordt onder het huis drie, vijf of zeven stuks bamboe gelegd op het "graf» der taboeni.

Bij de Mamah Darats zien we dat na de doorsnijding van den navelstreng het kind zevenmaal omhoog wordt gehouden en heen en weer gewiegd - manogah manampi - waardoor het tegen ziekelijkheid gevrijwaard is. $\mathrm{Na}$ vier dagen wordt een jongen, na drie dagen een meisje buiten gebracht en ten hemel geheven (tindjau awan).

$\mathrm{Na}$ vijftien dagen wordt het kind aan de badplaats gebaad. Bij de Ngadjoe's noemt men het naar buiten brengen van het kind, waar het op de palartaran (voorplatje) gebaad wordt, manahoenan; dit heeft drie of zeven dagen na de geboorte plaats.

In die streken waar het kind niet in de rivier gebaad wordt, of met de aardgeesten in contact wordt gebracht, gebeurt dit later. Men moet dan tot dien tijd het kind beschermen voor het zien der lucht. Vandaar dat de moeders, als ze haar kindje naar buiten brengen, zeer groote zonnehoeden (tangkoei dara) dragen, die ze eerst binnenshuis afzetten, en waardoor het kind beschermd wordt.

De groote ceremoniën betreffende de kennismaking met aarden watergeesten zullen we later behandelen.

$$
\S 70 \text {. De namgeving. }
$$

$\mathrm{Na}$ het mandiën zagen we, onder voorzitterschap van het Hoofd, de ceremonie der naamgeving plaats hebben. Bij de Sahiai Dajaks gaat deze plechtigheid, evenals bij de Ngadjoe's, op de volgende wijze. In een koperen schaal wordt rijst gedaan, waarin veertien rotan-stokjes worden geplaatst, die hampatangs moeten voorstellen. Te midden dier stokjes staat een ei. De verzamelde oudsten geven nu den popjes elk een naam, waarna de moeder met de kleine komt; het popje dat deze eerst grijpt stelt den naam van het kind vast. Bij de plechtigheid hangt boven de popjes een net, en een sawang-boompje staat gereed in een gong met rijst. Men noemt dit feest het nipas sahoei (nipas $=$ vrij), tamahian (O.D.). Na afloop worden kind en moeder met bloed besmeerd. De ouders veranderen na dit feest van hunnen eersteling hun naam in indai A. en amang A. (indoe, bapa, Ngad.).

Aan de Saroejan heeft dit feest voor een jongen zeven, voor een meisje drie of vijf dagen na de geboorte plaats, en heet daar 
pasoelang. Nadat het kind gebaad is, wordt tusschen eenige palen een varken opgehangen; dit wordt gedood en daaronder wordt een vuurtje aangelegd om het te roosteren. Thans brengt een vrouw het kind en een tweede een mandje rijst; het kind wordt door de moeder op schoot genomen en terwijl het Hoofd met rijst de beide personen bestrooit, wordt door den vader de naam genoemd. De slotvertooning is dat het kind wat toewak te drinken krijgt. Elke vrouw mag daarna het kind even op schoot nemen, maar moet daarvoor een kleinigheid betalen, het z.g.n. singè anka (singer anak). Na afloop wordt de sawangboom geplant. Deze staat in zeer nauwe verbinding met het kind; beschadiging wordt beboet.

In geheel Zuid Borneo zien we, dat de ouders zich naar hun eersteling noemen. Het is zeer natuurlijk dat bij een gewichtige gebeurtenis als deze - we zagen toch reeds boven welk een belangrijk deel van den persoon de naam is - veel aan het toeval, d. w. z. den wensch der goden wordt overgelaten. In het eerste geval zien we hoe de kleine een stokje grijpt, waaraan vooruit namen zijn gegeven. In het tweede geval zijn de namen meestal aan opvallende gebeurtenissen uit de laatst verloopen dagen gekozen.

Zoolang de kinderen klein zijn worden ze meestal met «lieve naampjes» aangesproken, b.v. awau (baby), sokei (vrouwelijk schaamdeel) oedang (garnaal). Zelden hoort men de kinderen bij hun eigen naam noemen.

Vraagt men een moeder den naam van haar kind, dan vervalt men in een kleine boete van $\pm f 0.50$; het vragen daarnaar is reeds pali.

Het tijdstip der geboorte is tevens van belang niet alleen voor de naamgeving maar ook voor het toekomstige geluk van den jonggeborene. Ook bij de Maleiers wordt daarop gelet; immers wie op Malam Maspoe geboren wordt zal òf vroeg sterven, òf geluk in het leven hebben.

\section{\$ 71. Het loon der bedan.}

Het loon der bedan wordt bij de Ngadjoe's betaald na het manahoenoen. Behalve het nieuwe stel kleeren, dat ze na de bevalling krijgt, wordt haar, ingeval een jongen geboren is, een rawajang of een pakihoe gegeven (pakihoe = lans om visch mee te steken, rawajang $=$ idem om groote visschen te vangen); 
voor een meisje wordt een langgei aan de bedan ter hand gesteld (langgei $=$ mesje om bamboe te splijten). Deze betalingen zijn de "sanaman".

Aan de bedan wordt voorts de even vóór de bevalling aan de vrouw omgebonden agaatkraal (maneloen lilis) afgestaan.

Geldt het hulp van een arm persoon, dan leent men wel voor den duur der bevalling van de bedan een lamiang; men noemt zulks imeteng sanda.

Voorts bekomt de bedan nog een slendang (nindjang), en verder nog haar loon (laloeh). Dit laatste wisselt zeer naar plaats en stand. Het voorgaande moet dubbel betaald worden, indien de afgang der kleine al dadelijk bevredigend is. Het eigenlijke loon wordt voorloopig maar ten halve betaald; de andere helft volgt later als het kind loopen kan en zich in goede gezondheid verheugt. Sterft het, of is het ziekelijk, dan komt niets van verdere betaling.

De bedan heeft zich na de bevalling gedurende drie dagen te onthouden van vuur aanmaken of ijzer aanraken; veronachtzaming daarvan zou opzwelling van den navel ten gevolge hebben.

Aan de Saroejan bedraagt het loon een boekong halamaung $( \pm f 5$.- ) en wordt later wederom zulk een pot betaald. In Kota Waringin wordt $\frac{1}{2}$ poelau kembang betaald (één poelau kembang $=$ twee tadjau à $f 2 .-)$, voorts nog één kain, één parang, één lamiang, één kip en één kolak padi (een kolak = $\frac{1}{2}$ gantang padi).

Ingeval een vrouw meer dan driemaal bevallen is, kan het loon verminderd worden.

\$ 72. Moeielijke bevalling.

De natuurmensch heeft over het algemeen zeer weinig moeite met het ter wereld brengen van kinderen. Komt er eene belemmering, dan is er groote ontsteltenis, en heeft men geen middelen om kunstmatig die hindernissen uit den weg te ruimen. Men bepaalt er zich toe af te wachten en door drukking op den buik het kind tot uitgaan te dwingen.

Daarbij ontbreekt het dan natuurlijk ook niet aan bezweringen, die de kraamvrouw kunnen helpen. We zien dan b.v. twee personen een rotanslinger boven de vrouw houden, een persoon houdt dien boven het hoofd vast, een andere aan het voeteneinde, en met een plotselingen ruk trekt laatstgenoemde de 
rotan naar zich toe, in de hoop dat ook het kind dat voorbeeld zal volgen.

Een andere methode is dat de echtgenoot van de vrouw driemaal over zijn vrouw heen stapt en daarna haastig door de deur het huis verlaat, hopende dat het kind evenzoo zich haasten zal, zijn verblijf te verlaten.

Weer een andere weg is, onder het roepen van "koer, koer» rijst tusschen de beenen van de vrouw te strooien. Men doet daarbij dan als lokt men kippen, en verwacht daarvan hetzelfde resultaat.

Helpt ook dat niet, dan zal men overgaan tot het doen ván beloften, om indien de bevalling snel afloopt een of ander offer te brengen aan de aangeroepen Sangiang. Men bindt bij dat gebruik de vrouw nog een agaatkraal om, terwijl men over haar buik een kip slacht, het bloed vrijuit latende loopen.

Dit alles geeft den Dajak hoop; onderwijl geeft hij de vrouw verschillende geneesmiddelen te drinken, die voor afdrijving bestemd zijn, maar de gezondheid van de toekomstige zuigeling geen voordeel zullen doen. Helpt geen van deze middelen, dan moet de vrouw in het kraambed sterven, wat vreeselijke gevolgen voor haar ziel zal hebben. De Ott Danoem houdt bij moeilijke bevallingen een balian-feest (njadah).

s 73. Bij\%ondere gevallen.

Indien de bevallingen niet de gewone resultaten hebben, geeft de Dajak daaraan natuurlijk een bijzondere beteekenis. Gaan we achtereenvolgens deze gevallen na.

Allereerst dan het geval dat een tweeling geboren wordt. Zijn deze van hetzelfde geslacht, dan is zulks niets, maar is het een jongen en een meisje dan staat de raak anders. De beide kinderen hebben dan - dat staat vast - in het moederlichaam reeds overspel gepleegd, of liever ze hebben zich schuldig gemaakt aan bloedschande, en moeten de consequenties daarvan dragen; het meisje moet sterven, op welke wijze ook. Dit is zeker, dat in de Dajakstreken geen tweeling in leven is gebleven, of in leven blijft, die van tweeërlei geslacht is. De jongen blijft leven of liever: men laat hem in leven. Ook komt het voor, als gevolg van het schenden der pali-bepalingen, dat de tweeling uit een mensch en een spook bestaat. Dit laatste verdwijnt dadelijk na de geboorte, en pleegt de menschen te hinderen door allerhande streken uit te halen, als kippen stelen enz. 
Wordt een kind met de beenen naar voren geboren, hantikang (Sar.), toeroen tangga (Mal.), dan moet men aan de Saroejan het sial, dat op zoo'n kind rust, bezweren door het om een veld te dragen, waar de rijst door hampangan (walang sangit) is aangetast. Is dit gebeurd, dan is het kind verder als geneesmiddel tegen deze ziekte van het rijstgewas te gebruiken. Het hoeft dan slechts om het veld te loopen. Alvorens de bezwering gehouden wordt, moet eerst reukwerk gebrand worden, liefst garoe-hout.

De Maleiers van Kota Waringin deelen deze meening en houden daarom zulke kinderen voor toeroenan Dewa. De Sahiai Dajaks achten het een onverdeeld gunstig teeken, dat het kind rijkdom voorspelt. In de meeste gevallen echter eindigt zulk een bevalling met den dood van moeder en kind.

Indien een kind met de helm geboren wordt is zulks een goed teeken. De helm wordt niet bewaard. Men noemt dit aan de Saroejan "basaroeba koendi hia». De Maleiers noemen zulk een kind anak menjoerban; het is een geluksteeken, want het kind zal een hadji worden.

Een andere geboorte-variëteit, waarvan ik den Nederlandschen naam niet ken, heet karong-karong.

Het kind is dan geheel in een huid verpakt, als het ware in een zak. Men moet vooral niet met ijzer daaraan komen, maar de vader moet met zijn tanden de huid vernielen, waarop het kind te voorschijn wordt gebracht. Men bewaart dit vel, en mengt het bij stukjes en beetjes in de spijzen van het kind. Het zal daardoor onkwetsbaar worden en een lang en gelukkig leven hebben. Raakt men echter met staal de karong aan, dan is de tooverkracht gebroken.

Baart een vrouw een albino, dan is dit het resultaat van gemeenschap met spoken; het kind blijft in leven en de vrouw moet de boete op overspel betalen.

$\$ 74$. De dood in het $\mathrm{kraambed}$.

De vrouw die in het kraambed sterft is gedoemd te blijven spoken. $\mathrm{Zij}$ zal haar sexegenooten hetzelfde lot trachten te doen deelen, en haar ziel zal niet het hiernamaals betreden. Ja zelfs bij de begrafenis zal men haar beenderen een afzonderlijke sandoeng geven, zooals bij de Sahiai haar raoeng niet in de gemeenschappelijke hoema raoeng zal worden ondergebracht. Zij 
is vervloekt; men hoort haar 's nachts, als ze rondwaart om slachtoffers te vinden, kenbaar als ze is aan haar steeds herhaalden kreet "hiai hiai». Ze is dan tot een gevreesde kemiah, konkianaq, pentianak geworden, d. z. wezens die allen onder Radja Pojang ressorteeren evenals de pojangs, die evenzeer kraamvrouwen lastig vallen. Deze zijn kenbaar aan scherpe nagels aan de vingers en zeer lange haren, die een groot gat in den rug bedekken. De pontianaq heeft op de plaats der maagstreek een gat.

De schuld van dit overlijden wordt gegeven aan den echtgenoot, die klaarblijkelijk de panti's niet heeft gehouden; de familie van de vrouw zal hem dan ook voor bloedgeld aanspreken, en wel aan de Saroejan acht hoeloen à f 40.- Men noemt het bloedgeld daar tanggoel.

Aan de Boelik bedraagt de betreffende boete zes losa. Aan de Katingan, waar deze boete heet singer pali pangarai, gaat een en ander als volgt in zijn werk. Zeven dagen na den dood der vrouw komen hare erven, die den man voor het sahiring (bloedgeld) aanspreken, hetwelk acht à negen djipen à $f 40$. bedraagt; voorts moet betaald worden "peraboet» d. i. één djipen (peraboet $=$ voor het wegnemen). De erven der vrouw ontvangen deze gelden.

Ook het bevallen in eens anders huis wordt gestraft. De Roekoe Dajaks noemen de te betalen boete «ketjemaraan darah», die één tadjau boekong beloopt, benevens de bestanddeelen voor een bezwering genaamd tampong tawar, waarvan de ingrediënten zijn: één ring, één mes en tampong tawar, hetgeen aan de Roekoe bestaat uit gele rijst met snippers van sawang-bladeren er door. De bezwering wordt gehouden door eerst den betrokken persoon met kippenbloed te bestrijken, en hem daarna met de tampong tawar te bestrooien.

\section{$\S 75 . \mathrm{Na}$ de bevalling.}

$\mathrm{Na}$ de bevalling is de vrouw nog niet vrij van de haar bindende pali-voorschriften. Thans bepalen ze zich echter in hoofdzaak tot dieet-voorschriften, behalve de bepaling dat ze alleen mag drinken uit bamboe voorwerpen; verder mag ze bepaalde vischsoorten niet eten en moet ze zich in hoofdzaak voeden met rijst in klapperwater gekookt, met een bamboe geleding als kookpan (memboeloeh). 
\$76. Zwangerschap en geboorte na een gedane gelofte.

In $\S 67$ hebben we geleerd hoe de geloften gedaan worden, we moeten nu met de inlossing daarvan kennis maken. Nadat de gewone ceremoniën zijn afgeloopen, wordt na de bevalling het balian hai gegeven, of heeft het slachten van een kip of ander beloofd offerdier plaats, een en ander op de wijze in \$ 34 aangegeven en gevolgd door een der andere bezweringen, al naar gelang der gedane gelofte. Het komt vaak voor, dat men aan het eind daarvan een nieuwe gelofte doet aan den behulpzamen geest, om, indien het afgebeden kind een bepaalden leeftijd heeft bereikt, een nieuw feest te geven. Zulke geloften doet men vooral aan Sangoemang, men noemt dit parapat sandahan bereng (instandhouding van het lichaam). Meestal wordt dan een zeer kostbaar feest toegezegd.

Hebben we thans gezien hoe het kind ter wereld komt, in de volgende hoofdstukken zullen we zijn leven leeren kennen.

$$
\text { (Wordt vervolgd). }
$$

